\title{
Monitoring Matters: Debt Seniority, Market Discipline and Bank Conduct
}

\author{
Piotr Danisewicz, Danny McGowan, Enrico Onali and Klaus Schaeck ${ }^{\dagger^{*}}$
}

\begin{abstract}
We examine if junior debtholders monitor banks and if such monitoring constrains risk-taking. Leveraging an unexplored natural experiment in the U.S. that changes the priority structure of claims on failed banks' assets, we provide novel insights into the debate on market discipline. We document asymmetric effects for monitoring effort depending on whether a creditor class moves up or down the priority ladder. Conferring priority to all depositors causes declines in deposit interest rates but increases interest rates for non-deposit liabilities, suggesting greater incentives for junior debtholders to exert monitoring effort. Consistent with the idea that senior claims require lower risk premiums, banks increasingly rely on deposit funding following changes in priority structure. More intensive monitoring also influences conduct: subordinating non-depositor claims reduces risk taking. Our results inform the debate about bail-ins and highlight that changes in the priority structure are a complementary tool to regulation which has received little attention in prior work.
\end{abstract}

Keywords: $\quad$ market discipline, debt priority structure, natural experiment, bail ins

JEL Classification: $\quad$ G21, G28

\footnotetext{
Acknowledgements

* We thank Diana Bonfim, Martin Goetz, Daniel Hardy, Florian Heider, Vasso Ioannidou, Ed Kane, Steven Ongena, Kasper Roszbach, David Skeie, Larry Wall, and conference and seminar participants at the, the Deutsche Bundesbank/ESMT/DIW conference in Berlin, and the ESCB Day Ahead Conference in Toulouse for very constructive comments and helpful suggestions.

† Bangor Business School, Bangor University. Email: klaus.schaeck@bangor.ac.uk. Tel: +44(0)1248 388540.
} 


\section{Introduction}

Modern finance theory states that debt priority has important implications for monitoring incentives. Conferring priority on one group of debtholders exposes junior claimants to greater losses in the event of bankruptcy, leading them to increase ex ante monitoring efforts. Exploiting a hitherto unexplored natural experiment in the U.S. banking industry, we provide novel insights into how market participants monitor and influence bank conduct following exogenous changes to the debt priority structure.

Market discipline, the idea that participants in financial markets can effectively monitor bank conduct and constrain risk taking, has been a cornerstone of the financial safety net for many years. The concept of harnessing market forces for regulatory purposes has also received considerable attention in the literature (e.g., Flannery (2001)). The mechanism works as follows: Private investors, in particular holders of large debt claims have strong incentives to monitor banks' risk exposure because their claims are not protected by deposit insurance (Flannery and Sorescu (1996)). Consequently, they have more to lose if a bank fails and are therefore more likely to respond to impending problems. Such responses may come in the form of withdrawal of funds, refusing to roll over funds, demanding a higher risk premium, demanding collateral, or combinations thereof. Ultimately, these actions put constraints on the risk-taking behavior of banks, in particular asset allocation choices (Goldberg and Hudgins (2002)).

However, the jury is still out on whether private sector agents reliably engage in risk monitoring and preventative influence of bank behavior. ${ }^{1}$ In terms of the monitoring dimension of market discipline, Flannery and Sorescu (1996) present evidence that investors monitor banks and can distinguish between risky and sound banking firms. Similarly, Martinez Peria and Schmukler (2001) find that depositors punish banks for risky conduct. On the other hand, Krishnan, Ritchken, and Thomson (2005) challenge these conclusions. The opinions regarding the preventative influence of market discipline also diverge. Bliss and Flannery (2000) argue that evidence for the influencing dimension of market discipline is virtually absent. This view finds empirical support in research by Billet, Garfinkel, and O'Neal (1998), and Krishnan, Ritchken, and Thomson (2005). In contrast, Ashcraft (2008) challenges these inferences. He documents that market participants can indeed influence bank behavior, in particular when investors can impose real constraints on banks.

In this paper, we take advantage of a largely unknown natural experiment to contribute to the unresolved debate about the efficacy of market discipline. At the heart of our identification strategy lies the staggered introduction of depositor preference legislation in 15 U.S. states between 1983 and 1993, explained in detail in Section 2 below. Depositor preference laws change the claim structure on a failed bank's assets by assigning a priority claim to depositors and subordinates non-depositors.

We investigate if debt seniority differentially affects monitoring incentives of different creditor classes and if monitoring by creditors also influences bank conduct. Economic intuition and prior work by Birchler (2000) suggest this is the case. Subordinating claims of general creditors to those of depositors eradicates costly duplication of monitoring effort when investors differ with respect to privately known information costs because non-depositors have more efficient monitoring technologies. Consequently, monitoring is reallocated towards the more efficient monitors, i.e., nondepositors. Depositors therefore require a lower interest rate which reduces funding costs and translates into higher bank profits. Simultaneously, the increase in monitoring should also incentivize bank management to adopt less risky strategies. ${ }^{2}$ In short, the introduction of depositor preference laws and the concomitant changes in claim structure give rise to a rich set of empirical predictions for funding costs, liability structure, profitability, and soundness. This is the focus of our study.

1 The debate about market discipline has received renewed attention in the aftermath of the recent financial crisis. Several observers note that the widely deployed government interventions such as blanket guarantees, liquidity support, capital support measures, and nationalizations undermine market discipline (e.g., Acharya and Kulkarni, 2014; Acharya, Anginer, and Warburton (2014); Calderon and Schaeck (forthcoming)).

2 This heterogeneity in "types" reflects the different monitoring costs incurred by depositors and non-depositors when monitoring bank performance. 
Our empirical setting is uniquely suited to draw causal inferences for the effect of the seniority of debt claims on bank conduct by exploiting variation across states over time in the introduction of depositor preference laws. In doing so, we overcome the typical identification challenges by establishing a valid counterfactual. The successive adoption of depositor preference legislation by 15 states constitutes a plausibly exogenous change in the monitoring incentives of non-depositors that only applies to state-chartered but not to nationally-chartered banks. This fact, together with the panel structure of our data with quarterly frequency, aids construction of the implied counterfactual.

We use difference-in-difference estimations that compare the evolution of the key dependent variables among state-chartered banks with an observationally similar control group of nationallychartered banks that are headquartered in the same state but are unaffected by the laws. We include bank fixed effects that rule out unobserved time-invariant effects in the cross-section, and we include state-quarter fixed effects that net out any time-varying unobservable heterogeneity on the statequarter level. In other words, our treatment effect simply represents the average difference between state-chartered and nationally-chartered banks in the same state-quarter, i.e., banks that operate in an identical macroeconomic environment. These design choices ensure that, conditional on additional covariates, the key identifying assumption that banks in the treatment and control groups are only randomly different is met.

One may ask whether the introduction of depositor preference is truly exogenous with respect to bank behavior. To alleviate concerns about the exogeneity of treatment, we survey the state legislative councils, read the legislative council's digests, the concurrencies of the state amendments and the assembly laws in all 15 U.S. states that adopt depositor preference during the sample period prior to embarking upon our econometric analyses. In addition, we screen a variety of press sources to gain an overview on the macroeconomic setting and the driving forces behind the adoption of depositor preference laws. This preliminary investigation decisively refutes the idea that banking sector conditions affect the introduction of depositor preference. We also do not find that macroeconomic developments correlate in any way with the adoption of these laws. The plausible exogeneity of depositor preference is also reflected in a set of empirical tests that model the adoption of depositor preference laws as a function of variables that provide information about the soundness and other characteristics of the 15 states' banking systems. Similar tests in the style of Kroszner and Strahan (1999) also reject the view that private-interest groups lobby for the introduction of depositor preference.

However, demonstrating that adopting depositor preference is orthogonal to the outcomes we study is not sufficient to establish causality. We must also show that our control group constitutes a valid counterfactual. We therefore present visual evidence that our data support the assumption of parallel trends between treatment and control group in the periods prior to the enactment of depositor preference legislation. These tests highlight that, in the absence of depositor preference laws, the key metrics we are interested in for both state-chartered and nationally-chartered banks would have evolved similarly. Subsequent empirical tests lend further support to this assumption.

We obtain the following key findings. Depositor preference laws provoke asymmetric monitoring responses depending on whether a creditor class moves up or down the priority ladder. Conferring seniority upon uninsured deposits causes a significant decrease in deposit interest expenses. By comparison, interest on non-deposits increase, reflecting their more junior status and greater ex ante incentive to monitor bank behavior to curtail losses in the event of bankruptcy. The overall effect of these changes is a $1.5 \%$ reduction in funding costs due to the composition of liabilities being more heavily weighted toward deposits.

Beyond documenting an important pricing effect for banks' cost of funds, we also isolate the quantity effects of priority changes. Consistent with the fact that insured depositors' position in the priority queue is unaffected by the law, we observe no change in state-chartered banks' market share of insured deposits. However, we do uncover a significant increase in state-chartered banks' share of uninsured deposits post treatment. This effect is consistent with uninsured depositors demanding a lower risk premium following their elevation in priority and a corresponding increase in the supply of uninsured deposits to state-chartered banks by risk-averse agents. Interestingly, we find that depositor 
preference laws have no effect on state-chartered banks' non-deposit market share. This suggests that part of the reason non-depositors increase monitoring is because they have the same amount of skin in the game. Put differently, had we found the laws to cause a decrease in non-deposits' market share it would be difficult to claim that non-depositors engage in more monitoring given they divest their holdings.

Do these changes in monitoring actually influence bank behavior in terms of risk taking and profitability? Our tests suggest they do. The average state-chartered bank's Z-score (ln) increases by $22 \%$, and non-performing loans ratios and leverage also improve. ${ }^{3}$ Thus, subordinating claims of private agents with efficient monitoring technologies causes significant improvements in soundness. We also find improvements in profitability: the average state bank's return on equity increases by $4 \%$.

Are the effects we attribute to changes in the priority of the claim structure really causal? Using bank-fixed effects that net out any unobserved time-invariant bank-specific heterogeneity mitigates omitted variable concerns. Likewise, state-quarter-fixed effects capture time-varying shocks, such as declines in demand and changes to tax rates and regulation that are common to both treated and untreated banks but differ across states, further alleviate problems that originate from omitted variables. In addition, time-varying bank-specific control variables purge the remaining realistic omitted variable threats. However, isolating the effect of depositor preference legislation requires that the changes in bank behavior can only be observed when depositor preference laws are introduced, and, moreover, that no other developments coincide temporarily with the adoption of depositor preference laws that could also trigger adjustments in banks' behavior. To address these issues, we offer a set of placebo regressions, where we randomly assign placebo depositor preference laws to nationally-chartered banks located in states where state-chartered banks were subject to depositor preference and find indeed that our placebo tests remain statistically indistinguishable from zero. The fact that we have 15 different instances of treatment occurring at different points in time makes it challenging to identify other potential confounds. Any omitted variable would have to temporarily coincide with the adoption of depositor preference and simultaneously only affect state-chartered banks. We discuss such potential confounds that occur simultaneously with the introduction of depositor preference in detail and present tests that rule out these alternative explanations. Specifically, we document that the banking turmoil in the S\&L industry, regional banking problems in Texas and New England, and the regulatory changes that come in the form of FIRREA and FDICIA do not drive for our findings. We also rule out that the wave of branching deregulation on the interstate and the intrastate level and charter switches play a role for our inferences. Tests that exploit the subsequent introduction of national depositor preference in 1993 help us demonstrate the external validity of our inferences.

Our findings are important for two reasons. First, the direct evidence that monitoring by junior claimholders translates in a corresponding improvement in bank soundness provides a rationale for market discipline being an integral component in the regulatory framework. Our inferences are consistent with Flannery $(1998 ; 2001)$ who advocates that private sector agents can effectively monitor financial firms. In contrast, our results counter concerns raised in recent work by Acharya, Anginer, and Warburton (2014) that market discipline has lost much of its appeal in the years after the crisis. Furthermore, our evidence mirrors findings in the corporate finance literature by Rajan and Winton (1995). They show loan contracts need to be structured in a way to provide incentives for the lender to monitor the borrower. We illustrate that assigning priority claims to depositors can be viewed as an alternative to contractual devices to motivate such monitoring in the context of banking regulation.

Second, the findings we obtain provide timely new insights for policy and regulation. Assigning priority to some or all deposits in case of bankruptcy of a bank has been one of the early ways of protecting depositors. The U.S. and a few other countries already have some form of depositor preference in place but this policy tool received little attention in the past few decades. However, a lively debate about the pros and cons of such legislation was sparked off in the aftermath of the financial crisis with policymakers and academics advocating the use of bail-in provisions where

\footnotetext{
In this study, we define leverage as the ratio of debt to equity.
} 
debtholders contribute to bank resolutions (Flannery (2010)). The European Central Bank called for the introduction of depositor preference laws in all member states of the European Union, and the Independent Commission on Banking in the UK also recommended the introduction of such laws. Policy makers favor adopting such laws on the grounds that they prevent bank runs, improve market discipline, and enhance soundness. However, they meet resistance from the banking industry whose representatives are concerned that such laws increase funding costs. In the absence of prior conclusive evidence on these questions, our work sheds new light into this debate and aids policy formulation.

Prior to summarizing our contribution, we briefly reflect on the fact that our inferences are based on data for U.S. banks obtained during the 1980s and early 1990s. We also discuss the extent to which we can generalize from our findings. Beyond highlighting that the banks in the 15 states that adopt depositor preference legislation are statistically indistinguishable from the population of banks in the U.S., we point out that our natural experiment also matters quantitatively. Banks in the 15 states that enter our main analysis account for 53 percent of total banking system assets in the U.S. Statechartered banks hold 47 percent of total banking system assets in these 15 states. The share of uninsured deposits in these banks is 9 percent of total liabilities, and non-deposits account for 15 percent of total liabilities. ${ }^{4}$ In other words, more than 24 percent of the liability side of a banks' balance sheet is affected by these laws.

In addition, we believe that there are other reasons for why our results are useful to inform the debate about market discipline in the U.S. and abroad. In fact, our experiment sheds light on how a banking system with many small and medium sized banks which operate in relatively small geographic markets on the one hand and a limited number of very large institutions on the other hand responds to an exogenous shock that increases monitoring by non-depositors. Many countries in Europe, primarily Germany, Austria, Switzerland, Italy, and Spain, have similarly structured banking systems with institutions that operate with comparable business models. Moreover, these smaller European institutions, just as their U.S. counterparts, typically do not rely extensively on wholesale funding and are often privately held, suggesting subdued levels of market discipline in general. In short, we believe our conclusions regarding the effect of assigning priority claims to bank depositors in the resolution process provide useful insights for the policy debate in several other countries.

We offer three key contributions to the literature. First, we illuminate the important debate about market discipline. In particular, we demonstrate, unlike most of the literature, that private sector agents not only monitor banks, but also causally influence bank conduct in terms of risk taking. The legal changes we focus on motivate non-depositors to collect information about banks' risk profiles and act upon it. Early work by Gorton and Santomero (1990), and Avery et al. (1988) does not find strong associations between bondholders' ability to price bank risk but subsequent studies conclude that investors and depositors are indeed able to do so (Flannery and Sorescu (1996); Flannery (2001); Goldberg and Hutchins (2002); Krishnan, Ritchken, and Thomson (2005); Martinez Peria and Schmukler (2001)). Further work in this area by Billett, Garfinkel, and O'Neal (1998) also challenges the capability of market participants to discipline banks. They show that market discipline deteriorates as banks become more risky because declines in bank health correlate with increasing use of insured deposits. In contrast to our work, these studies offer at best only evidence for the monitoring dimension of market discipline.

The intuition for why regulatory frameworks also try to harness market forces to constrain bank risk taking is the expectation that monitoring by market participants results in a corresponding influence on conduct. In other words, what really matters is if increased scrutiny by private sector agents that are exposed to losses in case of bankruptcy limits risk taking. Except for Ashcraft (2008), who shows holders of subordinated debt can exert preventative influence on conduct if they can impose real constraints via covenants, we know of no other study that delivers evidence for the influencing dimension of market discipline. In contrast to Ashcraft (2008), our setting does not require covenants to be in place. For our analysis, it is sufficient to have an increase in monitoring which is attributable to changes in priority claims mandated by law. This approach is more efficient than relying on

4 Note that state depositor preference laws do not distinguish between domestic and foreign deposits. Foreign deposits account for less than 7 percent of state-chartered banks' balance sheets. 
covenants as priority rules can be considered to be a substitute for private covenants that would be costly to write in the presence of transaction costs.

Another factor that distinguishes our research from previous work on market discipline is the fact that we pay attention to the mechanism that makes debtholders engage in monitoring and influencing of bank conduct. While many of the earlier studies we discuss above hone in on easily observable relationships between bond prices and bank risk, we are the first to show that shocks induced by changes in legislation that affect priority claims on a failed bank's assets have wide ranging implications for bank behavior. The magnitude of the effects we document in this work suggests considerable potential for depositor preference from the perspective of improving the institutional framework in banking which does not seem to have been sufficiently recognized in previous work.

The second contribution of our work is to shed new light on the role of depositor preference legislation, an issue of timely relevance for the policy community in the aftermath of the financial crisis which has triggered a massive overhaul of the regulatory framework with intensive debates about bank resolution.

Previous research has also focused on depositor preference in the U.S. In stark contrast to our work, Hirschhorn and Zervos (1990), Osterberg (1996), Osterberg and Thomson (1999, 2003) exclusively examine the introduction of national depositor preference in 1993 in the U.S., and largely limit themselves to analyses of the pricing effects of depositor preference, how depositor preference affects failure rates, and the losses incurred by the deposit insurer. The importance of our experimental setup becomes obvious when we compare our results with those of previous studies. Earlier work reports mixed evidence for the effect on funding costs as their empirical tests cannot disentangle the adoption of national depositor preference from other coinciding events. Moreover, Hirschhhorn and Zervos (1990) only examine the thrift industry. Unlike these papers, we present a natural experiment that permits isolating the effects from state-level depositor preference legislation that predates the introduction of national depositor preference. A further result that delineates our work from the earlier research is our finding that once national depositor preference law was enacted, state-chartered banks that were already subject to preferential treatment of depositors no longer display changes in funding costs and liability structure.

Related to these early studies on depositor preference is work by Hardy (2013). He develops predictions arising from depositor preference for funding costs, profitability, and the probability and cost of bankruptcy. He argues that claimants to the residual assets of failed banks lobby to assert claims to the share of residual assets, where lobbying is increasing in the volume of residual assets. The lobbying process increases bankruptcy costs as it extends the resolution period. Moreover, if one claimant takes legal action, the Nash equilibrium is for other claimants and the receiver to also take legal action. Since depositors enjoy a preferred status under depositor preference laws, no resources need be deployed to establish this position. In turn, the volume of residual assets non-deposit creditors fight over is reduced and so are bankruptcy costs. The implication for the probability of bankruptcy is straightforward: If depositor preference lowers banks' overall funding costs, ceteris paribus, the probability of bankruptcy will endogenously decrease. In contrast to his work which is exclusively theoretical, we take these issues to the data and test these predictions empirically.

The third contribution is that we are the first to exploit a so far neglected natural experiment that causes a switch in monitoring intensity by different groups of debtholders to study market discipline. Our experiment represents a useful source of plausibly exogenous variation in the monitoring activities by junior claimholders on a bank's assets. Such a switch in monitoring effort is also of relevance for other questions in banking, e.g., whether the additional monitoring by junior claimants produces new information that can be exploited for the allocation of supervisory resources and prudential regulation.

Finally, our study also advances the literature on bank capital structure and funding choices. This debate is relevant because bank funding models, not only in Europe, have been criticized for their vulnerability in the academic literature and by policy makers in the aftermath of the crisis (DemirgüçKunt and Huizinga (2010); Huang and Ratnovski (2011); Le Lesle (2012)). Importantly, regulating bank capital and developing rules that focus specifically on banks' liability composition have received 
a massive overhaul in the past few years. A substantial body of literature exists on banks' capital choices. Froot and Stein (1998) establish the association between risk management, capital budgeting, and capital structure in banks, and subsequent work by Cebenoyan and Strahan (2004) shows that credit risk management is a key determinant for banks' capital structure. Peura and Keppo (2006) report that differences in returns volatility and in the level of capital market imperfections are also important determinants of cross-section of banks' capital ratios. Berger et al. (2008) investigate how bank holding companies manage their capital structure, and Gropp and Heider (2010) echo results in the corporate finance literature by showing that bank-fixed effects explain most of the variation in bank capital ratios. The role of regulatory innovation is investigated by Flannery and Rangan (2008). They examine changes in bank capital structure and conclude that changes in regulation increased bank counterparties' monitoring incentives and price risk more adequately. Recently, Admati et al. (2013) propose higher minimum capital ratios are the best possible way to improve soundness, and Flannery (2014) discusses how regulators can ensure that banks maintain adequate levels of lossabsorbing capital, stressing that credible bail-in provisions lead junior debtholders to provide market signals when bank soundness deteriorates. Our paper differs from these two related strands of literature about capital structure and funding mix by paying particular attention to how different components of bank debt respond to an exogenously triggered switch in monitoring intensity by junior claimholders.

The paper proceeds as follows. Section 2 provides an overview about the legislative history of depositor preference legislation that underpins our quasi-experiment and several exogeneity tests. Section 3 describes the data and discusses representativeness. Our identification strategy and the main results are presented in Section 4. Section 5 deals with identification concerns, shows further sensitivity tests, and discusses the external validity. Section 6 contains concluding remarks.

\section{Institutional background: The staggered nature of depositor preference legislation}

The regulatory framework in the U.S. prescribes detailed guidelines for the resolution of failed banks. The assets of a failed institution are transferred to a receivership, represented by the Federal Deposit Insurance Corporation (FDIC) whose task it is to identify and satisfy creditors, and maximize the net present value of recoveries for the receivership claimants. We first provide a synopsis of the legislative history of the claim structure for a failed bank's deposits. Subsequently, we present empirical support for the exogeneity of depositor preference laws with respect to bank behavior, and we also rule out that interest-groups lobby for adoption of depositor preference.

\subsection{History of depositor preference legislation}

The FDIC, in its role as a receiver, pays off claimants in line with the guidelines for receiverships of banks established by the Banking Act of 1935. The FDIC assigns priority claims to the receiver who obtains part of the proceedings as compensation for administrative expenses. Next in line are secured claimants who have collateralized claims. ${ }^{5}$ They are followed by depositors with account balances below the deposit insurance coverage limit, with uninsured depositors whose account balances exceed the deposit insurance coverage limit and non-depositors coming thereafter. ${ }^{6}$ The latter two groups have claims of equal priority. Last in the queue are holders of subordinated debt, and shareholders.

Importantly, several states depart from the provisions laid out in the Banking Act of 1935, and change the priority structure of claims for state-chartered banks in their respective state banking laws. Starting in 1909, Nebraska established that depositors have a priority claim over the claims of general, i.e., non-deposit creditors. In the following years, 29 other states also adopted what has become known as "depositor preference laws", thus elevating the claims of all depositors, both insured and uninsured ones. Of those 29 states, 15 states (Arizona, California, Colorado, Connecticut, Florida, Hawaii, Kansas, Louisiana, Maine, Minnesota, Missouri, New Hampshire, North Dakota, Rhode Island, Texas) adopted depositor preference laws during our sample period 1983Q1 - 1993Q2. As we discuss below,

5 Secured claims receive priority only for the value of the collateral securing the claim. If the value of the collateral is less than the amount of the claim, the unsecured portion falls into the priority scheme according to the type of claim (Marino and Bennett (1999)).

6 Non-depositors include: trade creditors, beneficiaries of guarantees, foreign depositors, holders of bankers' acceptances, unsecured lenders, landlords, suppliers of Fed funds, and counterparties to swaps and other contingent liabilities. 
the differential treatment of claims on failed banks' assets depending on the type of charter is abolished in 1993Q3 with the introduction of national depositor preference.

Table 1, Panel A, highlights the staggered nature of the adoption of state depositor preference laws.

\section{[INSERT TABLE 1: THE POLITICAL ECONOMY OF DEPOSITOR PREFERENCE ADOPTION]}

How are these legal provisions embedded in state laws? To obtain the original text of the law, we contact the legislative council archives and the chartering authority in each one of these 15 states. Appendix A presents the codified law at that time for each one of these states that enter our empirical analysis. ${ }^{7}$ Typically, these provisions are found in a section entitled "Involuntary Liquidation Procedure", "Payment of Claims", or "Distribution of Assets". While the wording and some details differ across states, the priority structure for the claims on failed banks' assets with a state charter that emerges looks as follows:

1. administrative expenses of the receiver;

2. secured claims;

3. deposits, both insured and uninsured;

4. other general creditor claims;

5. subordinated creditor claims; and

6. shareholders.

Why did not all states introduce such legislation? Table 1, Panel A, and Figure 1 do not suggest any geographic clustering of states which are prone to adopt depositor preference laws. To gain a deeper insight into the motivation behind the introduction of depositor preference, we also screen the legislative council's digest, concurrencies of the state amendments, and the assembly laws themselves from the legislative council's archives. We also run keyword searches in the Journal State Legislatures, Lexis/Nexis, Factiva, and American Banker using a one year time window with 6 months on either side around the day of the introduction of depositor preference laws. ${ }^{8}$

The key result from our investigation of the documents from the legislative councils is that adopting depositor preference did not get much attention from the policy community. If anything, these changes are considered necessary to rectify omissions in previous legislation. California is an illustrative example. The concurrency of the state amendment mentions that the current law did at that time not specify a priority for the payment of depositors and creditors and liquidation expenses and instead requires pro rata settlement. The new legal provisions address this lack of a priority order comprehensively. In addition, assigning priority to depositors' claims is believed to facilitate the use of purchase and assumption transactions, and allows depositors to access their funds more quickly relative to liquidating a bank. In a limited number of other instances, the legislative council's digest highlights amendments for the reorganization and dissolution of state banks, and emphasizes that changes are being made to the order of priority claims in a bank's liquidation without providing a reason behind it.

Our keyword search of the media sources, limited again to one year centered on the event day of the adoption of depositor preference, does not provide any indication that the media paid much attention to depositor preference. The exception are sources reporting that the then FDIC Chairman, William L. Seidman, gave testimony to the Senate Banking Committee in 1986 recommending to adopt federal depositor preference to reduce failure cost. ${ }^{9}$ However, it took until 1993Q3 before depositor preference was codified in federal law, applying to all banks, irrespective of their charter type.

7 We exclude Utah and Virginia. These two states enacted depositor preference laws in 1983 but the absence of some variables and the annual sampling frequency in Call Report data prior to 1983 renders the inclusion of these two states in our empirical analyses infeasible.

8 We use the following keywords: "deposit obligation", "depositor obligation", "claims of depositors", "claim structure", "bank liquidation", "depositor preference", "priority of claims", "priority claim", "liquidation priority", "liquidation regime”, "claims be paid before those of general creditors", "pari passu with general creditors", "deposit rank", "depositor rank".

9 See American Banker, $14^{\text {th }}$ March 1986 "FDIC offers plan to protect uninsured depositors". Similar news reports occur in the same week in the Chicago Sun Times, the New York Times, and on Dow Jones Newswire. 
Appendix A provides further details about the political and economic environment at the time the individual states adopted depositor preference. We conduct an additional keyword search in American Banker, Lexis/Nexis and Factiva to identify any other events that may have coincided temporarily with the changes in priority claims to understand whether particular episodes of banking strain or political economy considerations play a role for the introduction of depositor preference laws. ${ }^{10}$

Depositor preference laws are somewhat more often found in states with Democratic Party governors, and when democrats hold control of both the upper and the lower house of the legislature. However, our analysis of other key events yields no consistent pattern. In several states, the news search produces no relevant information that would have any bearing on the motives to introduce depositor preference. Occasionally, the media pays attention to bank mergers (Arizona, California) or reports that banks are performing well in Florida, Hawaii, and Minnesota. On the other hand, there is also evidence that banks in the South West (Texas, California) and in the North East (Main, New Hampshire, Connecticut, Rhode Island) experience considerable strain arising from collapsing real estate and energy prices.

In 1993, the legislative history takes another turn on 10 August when the Clinton administration amends the Federal Deposit Insurance Corporation Act regarding the priority of claims on assets of a failed bank and introduces national depositor preference as part of the Omnibus Budget Reconciliation Act.

As a result, claims on failed state-chartered banks in states that previously did not have depositor preference and claims on nationally-chartered banks now also had priority above those of general creditors. National depositor preference has the same effects as had state laws for state-chartered banks except that national depositor preference distinguishes between domestic and foreign deposits. In a similar vein as our review of the individual state's adoption of depositor preference suggests, national depositor preference was also not driven by concerns about bank safety and soundness. Instead, national depositor preference was principally introduced to save money in the federal budget rather than to facilitate the resolution of ailing banks via purchase and assumption transactions or increasing market discipline by providing stronger incentives for non-depositors to monitor banks. These reasons are put forward by the FDIC which has been lobbying since the mid-1980s for such guidelines. In fact, the budgetary purpose of the law received attention in the media while the bill was moving through Congress, in contrast to any mentioning of safety and soundness considerations. Legal scholars such as Curtis (1992, p. 244) are more explicit in their assessment of the motivation behind this law stating,

"[...] the depositor preference regime was not enacted for reasons having to do with safe and sound bank regulation or with orderly liquidation, but rather, as indicated by its inclusion in the Omnibus Budget Reconciliation Act of 1993, entirely for budgetary reasons - it was a means for the federal government to spend less money."

\subsection{Exogeneity of depositor preference legislation and bank conduct}

Our survey of the legislative history and motivation behind the introduction of state depositor preference laws does not suggest that the health of the state banking systems was a key force behind the adoption of this legislation. However, to claim causality in our subsequent tests, we need to establish the exogeneity of these laws with respect to the outcomes our research focuses on.

To this end, we estimate linear probability models in which state depositor preference laws are a function of private interest-group, public interests, and political-institutional factors to understand how changes in these variables over time and across states affect the likelihood of depositor preference. Our strategy entails estimating the following reduced form

10 The keywords are: "bank" OR "banking" OR "financial institution" OR "depository" AND OR "budget deficit" OR "budget surplus" OR "oil shock" OR "unemployment benefit" OR "S\&L crisis" OR "Savings and Loans crisis" OR "Federal Savings and Loan Insurance Corporation" OR "FIRREA" OR "Merger and Acquisitions" OR "M\&A“ OR "Dividends" OR "Earnings" OR "Deregulation" OR "Expedited Funds Availability Act". 


$$
D P L_{s t}=\alpha+\beta \text { Private }_{s t}+\gamma \text { Public }_{s t}+\delta \text { Political }_{s t}+\gamma_{s}+\gamma_{t}+\varepsilon_{s t},
$$

where $D P L_{s t}$ is a dummy variable equal to 1 if state $s$ has enacted depositor preference law in quarter

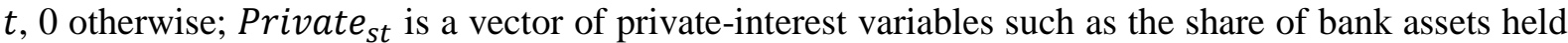
by state-chartered banks within the state-quarter; Public ${ }_{s t}$ contains a proxy for the extent to which a state is affected by the S\&L crisis (measured as the ratio of assets in failed thrifts to total bank assets), total assets in failed banks (ln), and the mean profitability of banks in the state; Political ${ }_{s t}$ contains a dummy variable equal to 1 if a democrat is state governor, 0 otherwise, to capture differences in regulation propensity between political parties (Krozner and Strahan (1999)). State and quarter-fixed effects are denoted by $\gamma_{s}$ and $\gamma_{t}$, respectively, and $\varepsilon_{s t}$ is the error term. The sample window corresponds to that used in our subsequent main empirical analyses, 1983Q1 to 1993Q2, for the 15 states that adopt depositor preference law. We cluster standard errors at the state level.

The results of this exercise, shown in Panel B of Table 1, substantiate our previous argument. Specifically, we find no evidence that private, public, or political factors systematically predict whether a depositor preference law is in force. Irrespective of whether we include each interest vector sequentially (Columns 1 to 3 ) or simultaneously (Column 4) in the equation, none of the explanatory variables assume significance at conventional levels. In sum, the enactment of depositor preference laws for state-chartered banks appears to be as good as random.

We briefly also explore as to whether the banks in the treatment and control group differ in terms of the key observables prior to the introduction of depositor preference legislation. Panel $\mathrm{C}$ in Table 1 illustrates that the $t$-statistics for differences in means for total interest expenses, interest on deposits, interest on non-deposits, bank size (in terms of total asset), and the capital ratio remain insignificant at conventional levels. This snapshot suggests our control group is observationally very similar to the treatment group.

Our final diagnostic test uses Cox proportional hazard models to examine whether movements in our variables of interest precipitate enactment of depositor preference laws. If so, the assumption of treatment exogeneity would cease to hold. However, the results in Table 2 confirm that the dependent variables we use in the regression analysis do not explain implementation of the state laws, adding further credence to the argument that these are exogenous shocks.

\section{[INSERT TABLE 2: EXOGENEITY TESTS: COX PROPORTIONAL HAZARD MODELS]}

\section{Data and methodology}

In this section, we first describe our data. Next, we then discuss our econometric setup, paying particular attention to the identifying assumptions of difference-in-difference estimation.

\subsection{Data description and representativeness}

We obtain quarterly data for commercial and savings banks in the U.S. from their Quarterly Report on Condition and Income (Call Report), available from the Federal Reserve Bank of Chicago.

Our sample window covers the period 1983Q1 to 1993Q2. This time span is chosen because banks were not obliged to submit Call Reports on a quarterly basis before 1983 and because the Omnibus Budget Reconciliation Act was signed into law in 1993Q3, resulting in all banks being subject to depositor preference laws. This results in a sample containing 528,522 observations for 15,392 banks from all 50 states. However, most of our inferences are based on a smaller sample consisting of banks headquartered in the 15 states that enacted depositor preference law between 1983Q1 and 1993Q2. This results in a cleaner sample of 199,698 observations for 5,506 banks.

We exclude banks operating in New York state due to their size and specific regulatory environment (Osterberg (1996)). To ensure that we have a sufficiently large number of observations for each individual bank, we only include institutions that operate in at least four quarters prior to and following the introduction of state depositor preference laws. ${ }^{11}$

11 The results are however unchanged when we include New York banks in the sample. Likewise, when we include banks that do not operate at least four quarters before and after the law change in the sample the results are almost identical. 
Panel A of Table 3 presents summary statistics. The average bank in our sample has 108,969 TUSD total assets, a Z-score of 72.793 , and a return on assets of $0.3 \%$.

To establish representativeness, we also compare the banks in our 15-state sample with the average bank in the U.S. using the entire population of banks in 1993. The mean asset size for all banks in the U.S. is 130,943.5 TUSD, with a Z-score 120.6, and return on assets of $0.3 \%$. Panel B of Table 3 presents Wilcoxon rank tests for the equality of means between the banks in the sample and the population of all banks in the U.S. for selected variables measuring asset size, profitability, and soundness. Except for a weakly significant difference at the ten percent level for bank soundness, these tests suggest that there are no significant differences in terms of asset size and profitability.

\section{[INSERT TABLE 3: SUMMARY STATISTICS AND REPRESENTATIVENESS]}

\subsection{Identification strategy}

We turn to difference-in-difference estimations that exploit plausibly exogenous variation in depositor preference law across U.S. states and across time. This setup enables us to retrieve the average treatment effect of depositor preference laws by comparing the evolution of funding costs, liability structure, soundness, and profitability between the treatment group (i.e., the state-chartered banks) and the control group (the nationally-chartered banks) through time.

Except for the first set of tests in Section 4.1 below which use banks from all U.S. states to include the largest possible control group of banks with similar pre-treatment trends during the 1983Q11993Q2 period, our estimations are constrained to the 15 states that adopted depositor preference legislation. This setup facilitates identification. These banks operate within the same environment, resulting in a cleaner economic laboratory because all confounding effects that simultaneously affect both groups can be eliminated. In other words, our estimator considers the time difference of the group differences within the same federal state, i.e., it accounts for omitted variables that affect treatment and untreated banks equally. For the main regressions we focus on the period 1983Q1 to 1993Q2, and estimate

$y_{i s t}=\alpha+\beta D P L_{s t} *$ Charter $_{i}+\delta X_{i s t}+\gamma_{i}+\gamma_{s t}+\varepsilon_{i s t}$

where $y_{i s t}$ is a dependent variable for bank $i$ in state $s$ at time $t$, capturing either the cost of funds or liability structure, bank soundness, or profitability; $D P L_{s t}$ is a dummy variable equal to 1 for all banks in states and years following introduction of depositor preference law or zero otherwise; Charter $_{i}$ is a dummy variable equal to 1 for all state-chartered banks, 0 for nationally-chartered institutions. $X_{i s t}$ is a vector of bank-time varying control variables defined in Section 3.3 below; $\gamma_{i}$ and $\gamma_{s t}$ are bank and state-quarter effects, respectively. This battery of dummy variables allow us to rule out all unobservable time-invariant bank-specific factors, and state-time-varying forces at the state and national levels, that might drive changes in the dependent variables and coincide with the introduction of depositor preference laws. Moreover, the inclusion of state-quarter fixed effects provides very clean identification of the average treatment effect as we exploit cross-charter variation within the statequarter dimension of the data set. The term $\varepsilon_{i s t}$ is the error term. Our coefficient of interest is $\beta$. Its magnitude provides information about the effect of depositor preference laws for state-chartered banks. As is customary when using difference-in-difference regressions, we cluster heteroskedasticityadjusted standard errors on the bank level to account for serial correlation within each panel (Bertrand, Mullainathan, and Duflo (2004)). Subsequent robustness tests show our findings are not affected by alternative ways of clustering.

\subsection{Variable definitions}

To establish whether assigning priority to depositors' claims in a bank insolvency changes monitoring activities and also triggers changes in bank conduct in terms of risk taking, our empirical tests focus on three key outcomes.

First, we examine the monitoring dimension of market discipline. Several previous papers have attempted to provide evidence of market discipline by examining interest rates paid by commercial banks (Goldberg and Hudgins (2002)). If depositor preference lowers the risk of all depositors they should demand a lower interest rate. In contrast, since non-deposit claimants face a higher risk in case 
of failure, they are likely to demand compensation for bearing more risk and will therefore demand a risk premium. Thus, depositor preference legislation should trigger a pricing response, depending on the seniority of the debt claim.

Our first set of tests therefore examines different components of banks' funding costs. Specifically, we use a variable measuring average interest expenses on all liabilities (Total interest expenses), calculated as the ratio of total expenses on liabilities to total liabilities. We also focus on the costs of deposits, using the ratio of interest paid on deposits to total deposits held by banks (Interest on deposits). ${ }^{12}$ The costs of non-deposit funds (Interest on non-deposits) are captured by the average interest expenses on non-deposits divided by total liabilities. This variable encompasses both Federal Funds purchased, and other non-deposit funds. The former are computed as expenses on Federal Funds purchased, and the latter are calculated as expenses on other non-deposits.

Second, it is plausible to anticipate not only price but also quantity effects. We therefore explore how state-chartered banks' market share of insured deposits, uninsured deposits, and non-deposits (all scaled by the total of this variable held by both state- and nationally-chartered banks in that statequarter) respond to the laws.

The third set of analyses is concerned with the influencing dimension of market discipline. Assuming non-depositors are efficient monitors, we should be able to observe changes in bank conduct in terms of banks' propensity to take risk, reflected in lower Z-scores, lower non-performing loans, and reduced leverage. The Z-score is an accounting-based measure of banks' distance to default, calculated as the sum of return on assets and the equity-to-asset ratio divided by the standard deviation of the return on assets, calculated over a four-quarter rolling time window. This time window allows for sufficient variation in the denominator of the Z-Score, and avoids that Z-Scores are driven exclusively by variation in the levels of capital and profitability. The skewed distribution of the Zscore necessitates a log transformation, and all tests are based on Z-score (ln). A higher Z-Score (ln) implies a lower probability of insolvency. As part of the analysis of banks' risk taking, we also decompose the Z-score into its three components and subsequently also examine alternative measures of profitability by analyzing return on assets, and the ratio of total interest income to total loans (TIINC) which is measured in logarithms, and return on equity (ROE).

The vector of time-varying control variables, $X_{i s t}$, includes total assets (ln) to measure bank size, and we also use the ratio of equity capital to total assets as a measure for the capitalization of the bank. To avoid that the S\&L crisis confounds our inferences, we also add a proxy for the intensity of the S\&L crisis, measured by the ratio of failed thrift assets to total bank assets in the state, in the regressions that exclude state-quarter fixed effects. Depending on the regression specification, the vector of control variables may also contain two dummies that take on the value of one if a state has deregulated interstate or intrastate branching, respectively.

\subsection{Do nationally-chartered banks constitute a valid counterfactual? Parallel trends}

We have already documented that treatment status is plausibly exogenous with respect to the outcomes we study. However, the validity of difference-in-difference estimation also requires that nationally-chartered banks constitute a valid counterfactual. That is, in the absence of treatment the behavior of the state-chartered banks in the treatment group would have evolved in similar fashion to the behavior of the nationally-chartered banks in the control group. In other words, the treatment and control groups should have parallel trends in the period prior to treatment. This section provides empirical support for the existence of such parallel trends.

Figure 1 graphically examines the extent to which cost of funds, liability structure, soundness, and profitability evolve similarly over the three quarters prior to the introduction of depositor preference laws. ${ }^{13}$ State-chartered banks are the treatment group and are represented by a blue triangle, and

12 Since data on expenses on deposits above $\$ 100,000$ are not available for our sample period total interest expenses is a measure of average costs of total deposits both secured and unsecured deposits.

13 In Section 4.5.2 we conduct placebo tests to examine whether the path of the dependent variable in the control group changed following treatment to rule out the possibility that our average treatment effect is confounded by bias in the implied counterfactual. 
nationally-chartered banks (the control group) are denoted by a red square. The close fit between the movements in the two groups suggests that nationally-chartered banks appear to represent a good counterfactual.

\section{[INSERT FIGURE 2: PARALLEL TRENDS]}

In addition to illustrating the evolution of bank behavior graphically, we conduct $t$-tests to verify the assumption of parallel trends. Following Lemmon and Roberts (2010), we examine whether there are significant differences in the quarterly growth rate of each variable between the treatment and control group during each pre-treatment quarter. Note that this assumption does not require identical levels between treatment and control groups, they are differenced out (Lemmon and Roberts (2010)). The diagnostics in Table 4 support the assumption of parallel trends: the null of equality of means cannot be rejected in any cell in the table.

\section{[INSERT TABLE 4: PARALLEL TRENDS TESTS]}

\section{Empirical results}

We first discuss the pricing effects of depositor preference on banks' funding costs, and then present the findings for the quantity effects and focus on market share. Next, we provide a long term perspective, and our final set of results considers bank soundness and profitability.

Importantly, all these regressions include bank-fixed effects to eradicate time-invariant effects such as individual banks' risk taking culture, time-varying bank-level control variables, and a set of statequarter-fixed effects that control for unobservable time-varying common shocks such as contractions in the local economy that may affect the demand for banking services.

\subsection{Pricing effects: Cost of funds}

The difference-in-difference regressions in Table 5 present in Panel A the results using the sample for all 50 states for the pricing effects from depositor preference. We show results with and without control variables for bank size, capitalization, a proxy for the intensity of the S\&L crisis, and the two dummy variables for inter- and intrastate deregulation.

Irrespective of the inclusion of control variables in Panel A, our tests highlight that assigning priority to bank deposits lowers overall funding costs. Importantly, we find compelling evidence for increases in market discipline.

The second set of regressions in Table 5 Panel B restricts the sample to the 15 states that adopt depositor preference laws during the sample window. In other words, our econometric setup gets tighter in terms of identification since the tests in Panel B are based on a cleaner counterfactual. This is because our control group is constrained to nationally-chartered banks headquartered in the same macroeconomic environment.

Our key coefficient of interest on the interaction term between the charter dummy and the dummy variable for depositor preference enters significantly with intuitive signs across all specifications. Since Panel B is our preferred specification as discussed above, all subsequent analyses and the corresponding discussion of results are based on this smaller sample. All results are however robust to using the 50 state sample.

We obtain clear evidence that depositor preference legislation affects bank's funding costs. Statechartered banks' total funding costs decline, reflected in the ratio of total interest expenses to total liabilities. Using the more conservative estimates from Panel B, our tests indicate that interest expenses to total liabilities fall by 0.0192 following enactment of depositor preference: equivalent to a $1.5 \%$ decrease in average interest expenses holding total liabilities constant. ${ }^{14}$

Which liability components drive this effect? Column 2 in Panel B confirms the prediction by Hardy (2013) that depositor preference laws reduce interest payments to (insured) depositors ( $t$-statistic 4.56). However, Panel B Column 3 highlights that other creditors require compensation in return for

14 Note that we obtain virtually identical results if we include a charter time trend to capture the time trend that affects all state-chartered banks equally across the US. The results are presented in Appendix B, Table B.1. 
having their claims subordinated to the FDIC with higher interest payments ( $t$-statistic 6.31). The coefficient indicates that the increase in interest payments to non-depositors is approximately seven times larger than the coefficient for the decrease in interest payments to depositors.

Among the control variables, we find that bank size correlates positively with all types of funds, whereas better capitalized banks pay lower interest, except for non-deposits, where we obtain a positive and significant effect.

\section{[INSERT TABLE 5: PRICING EFFECTS OF DEPOSITOR PREFERENCE]}

\subsection{Quantity effects: market share analysis}

Table 6, Panel A, focuses on the corresponding quantity effects. Column 1 indicates that changes to the debt priority structure have no effect on state-chartered banks' market share of insured deposits. This makes sense given that insured depositors position in the pay-out ladder is unaffected by depositor preference laws. However, in Column 2 we find a statistically significant 13 percent increase in state-chartered banks' market share of uninsured deposits. This increase is sizeable in terms of its economic magnitude and suggests that risk-averse uninsured depositors increase supply to statechartered banks. A rightward shift of the uninsured deposits supply curve is also consistent with the previous result that conferring seniority on this creditor class leads them to demand a lower risk premium.

\section{[INSERT TABLE 6: QUANTITY EFFECTS AND LONG-RUN EFFECTS]}

In Column 3 we do not find a statistically significant average treatment effect for the market share of non-deposits. Non-depositors do not divest their holdings in state-chartered banks post treatment. However, once their claims are subordinated they face greater exposure to losses in the event of bankruptcy. As a result non-depositors demand a higher ex ante interest rate in compensation.

\subsection{Do the effects persist in the long run?}

Our results so far indicate both statistically and economically large effects of the introduction of depositor preference. We now focus specifically on the question of whether the impact of depositor preference is only observable in the short run, or, alternatively, if the effects are permanent and can be observed over longer periods of time.

We augment the regression specification from our main tests with nine dummy variables corresponding to the quarter in which the legislation was enacted and a dummy variable for quarter $i$ where $i=\in(0, \ldots, 9)$ denotes the quarter after enactment. $i=0$ is the quarter of enactment. The additional dummy variables are interacted with the charter dummy. Panel B of Table 6 shows that the effects of depositor preference persist in the long run. There is an immediate and permanent decline in total interest expenses and interest payments on deposits, and the effects are also similar in terms of the economic magnitude. The previously documented increase in interest on non-deposits is also of permanent nature but it takes one quarter to materialize. Our findings are intuitive. The funding cost advantage arising from depositor preference is persistent, enshrined in law, and therefore lowers the probability of bankruptcy in all future periods.

\subsection{Effects on bank soundness and profitability}

Beyond the immediate pricing and quantity effects that arise from increased monitoring, it is critical to document whether the increase in market discipline also influences bank risk taking, a key concern among bank regulatory agencies. The importance of this test is reflected in the fact that the lobbying by the FDIC for the introduction of national depositor preference prior to 1993Q3 paid close attention to the argument that depositor preference will incentivize banks to operate safe and sound.

To test this prediction of whether an increase in monitoring explains the variation in banks' risk taking, we run regressions in Table 7, Panel A. Here, we use the Z-score (ln) as a dependent variable to test these ideas. ${ }^{15} \mathrm{We}$ also use the ratio of non-performing loans and the leverage ratio as dependent

15 Note that of the 5,506 banks in the sample, only a small proportion of banks is publicly listed. For this reason, we only rely on accounting based measures of bank soundness. 
variables in Panel A. Subsequently, we also examine the effect of depositor preference laws on the three components of the $\mathrm{Z}$-score (ln) to understand the driving forces behind the effects we uncover.

State-chartered banks' Z-scores (ln) increase significantly following the announcement of depositor preference laws, supporting the idea that harnessing market discipline improves bank health. The magnitude of this effect is economically large at $22 \%$. The findings for non-performing loans and leverage reinforce the soundness-enhancing effects of depositor preference laws.

Our analysis of the components of the Z-score (ln) shows that this finding is driven by higher profits ( $t$-statistic 3.20) although there is no change in the volatility of profits. This increase in profitability, reiterated in Panel B when we examine return on equity, and the ratio of total interest income to total loans (ln) as alternative measures of profitability, ties in with the result for lower levels of nonperforming loans and points towards increased asset quality. Consistent with improved behavior, we also find reductions in the non-performing loans ratio and leverage, although the effects are only significant at the 10 percent level.

\section{[INSERT TABLE 7: BANK HEALTH AND PROFITABILITY]}

\section{Identification concerns, sensitivity tests, and external validity}

We have already documented that state-chartered and nationally-chartered banks are observationally similar prior to treatment in terms of the levels of key characteristics.

Importantly, however, our identification strategy assumes that, in the absence of treatment, statechartered banks evolve similarly over time as national banks. In Section 3 above, we have already shown that treatment and control groups display such parallel trends. Moreover, we also offer support for the assumption that treatment is plausibly exogenous with respect to the outcomes we study.

\subsection{Potential confounds and omitted variables}

We now deal with the remaining concern: Omitted variables and confounding events. If the enactment of depositor preference legislation coincides temporarily with other factors that are not accounted for or unobservable to the econometrician and only affect state banks but not nationallychartered banks then we would misattribute the effects we document to the passing of state depositor preference laws when in fact other factors are responsible for the observed changes in bank conduct.

Dummy variables can only bulletproof observational data to omitted variable problems to a certain extent. Importantly, our tests are based on within state-quarter comparisons of state and nationallychartered banks for 15 states which adopt depositor preference legislation in a staggered manner. All regressions include time-varying controls, bank-fixed effects which net out omitted variables that are time-invariant on the bank level, and state-quarter-fixed effects to net out unobserved heterogeneity on the state-quarter level. This setup makes it unlikely that regional macroeconomic conditions, demand conditions, or changes in regulation which affect all banks equally drive the behavior of our key coefficient. Any omitted variable that could confound our inferences has to differentially affect state and nationally-chartered banks within the same state. Moreover, such an omitted variable would have to coincide with enactment of depositor preference in 15 instances. Finding such a coinciding factor is less likely in our context than in a study with just one treatment.

Our first candidate for such a change in bank characteristics over time which may systematically correlate with the outcomes of interest and coincide with the adoption of depositor preference is bank size. The analyses above show that funding costs correlate with size in a systematic manner. We therefore include in Table 8, Panel A, an interaction between size in terms of total assets and a dummy for state-chartered banks (zero otherwise) because the behavior of state and nationally-chartered banks could differentially be affected by size. Similarly, we add to this specification an interaction between size in terms of total assets and our dummy for depositor preference (zero otherwise).

While the former interaction term remains insignificant, the latter interaction enters consistently negatively and significantly. However, our key coefficient on the interaction term between the charter dummy and the depositor preference law dummy remains very similar. 
Next, we deal with the challenge that banks may have been concerned about the potential implications for their funding costs and therefore switch charters to circumvent the increase in monitoring from non-deposit claimants associated with depositor preference. While our review of the legislative history about the introduction of depositor preference does not suggest an intensive debate in the run up to the enactment of these provisions in state laws, we cannot rule out that banks are concerned about effects on their funding costs. Rosen (2005) documents that approximately $10 \%$ of banks switch their charter between 1977 and 2003, and that switching banks tend to be riskier. During our sample period $3.8 \%$ of banks change charter ${ }^{16}$

To rule out that concerns about funding costs drive changes in bank conduct, we present in Panel B of Table 8 linear probability regressions that models charter switches as a function of introducing depositor preference laws, bank-fixed effects, quarter-fixed effects, and the time-varying control variables we use in the main regressions. The key coefficient in these regressions, the dummy for the introduction of depositor preference, remains statistically indistinguishable from zero. Charter switches are not related to priority for depositors in the resolution process. ${ }^{17}$

In a second step, we remove banks that change their charter from the sample. The results, shown in Panel C of Table 8, fully reinforce our previous findings.

\section{[INSERT TABLE 8: INTERACTIONS WITH BANK SIZE AND CHARTER SWITCHES]}

Next, we review a series of events and regulatory changes that occur throughout our sample period, and discuss whether or not they qualify as confounding events. For each one of these events, we additionally present tests to rule out empirically that they have any bearing on our inferences.

The 1980s and 1990s are characterized by a series of banking problems caused by maturity mismatches, fraud, and declining real estate and energy prices.

Collapsing real estate prices after a wave of burgeoning growth triggered banking problems in New Hampshire, Connecticut, Massachusetts, and Rhode Island. In New England, 16 banks failed in 1990, 52 in 1991, and 43 in 1992. These failures account for a large proportion of failed bank assets at the time, resulted in losses to the FDIC, and culminated in the failure of three subsidiaries of the Bank of New England Corporation, the most significant bank failure in that period. This New England banking crisis, as it became known, coincides with the signing into law of depositor preference laws in 1991 in Connecticut, Maine, New Hampshire, and Rhode Island.

Moreover, Texas also experienced substantial banking problems. The banking industry in Texas which adopted depositor preference in 1985 with its large exposure to the energy industry was hit by a massive decline in oil prices in 1986. In addition, a tax law which reduced the incentive to hold real estate aggravated the economic malaise. In some areas, real estate prices for commercial property dropped by 30\% between 1985 and 1987 (Gan (2004)).

The last prominent confounding crisis event is the savings and loan (S\&L) crisis with over 1,000 failures of the 3,234 S\&L associations across the U.S. between 1986 and 1995. This crisis was largely driven by a large-scale tax reform in 1986 which brought the previous real estate boom to a halt, deregulation of the savings and loans associations which allowed them to enter new business lines, a period of low inflation, and forbearance by regulatory agencies.

While these three crises coincide with the adoption of depositor preference, it is difficult to see how they differentially affect state- and nationally-chartered banks. Nevertheless, we provide empirical support that these three crises do not confound our inferences.

Table 9 presents regressions. The first set of tests in Panel A removes observations for Connecticut, Maine, New Hampshire, and Rhode Island between 1991 and 1993 to focus on the New England crisis, and the second test in Panel B removes all observations for Texan banks from 1986 onwards. In

16 During the sample period, 118 banks switch from state to national charters ( 77 after depositor preference), and 92 banks change charter from national to state charters (77 after depositor preference).

17 In unreported regressions, we also estimate difference-in-differences regressions using linear probability and probit models that include the interaction of the dummy variables for state-chartered banks with the dummy for depositor preference. This interaction term also remains insignificant. The results are available upon request. 
Panel $\mathrm{C}$, we include additional interaction terms between the dummy for state-chartered banks and a proxy for the intensity of the S\&L crisis (measured as the ratio of failed thrift assets to total bank assets in that state), and a triple interaction term between the dummy for state-chartered banks, the dummy for depositor preference, and the proxy for the $\mathrm{S} \& \mathrm{~L}$ crisis. This approach departs from our method of investigating the role of the crises in Texas and New England because the depth and severity of the crisis differed across states and our method ensures the inferences are not confounded by coincidental S\&L shocks within the state-quarter. These tests confirm our expectation that these episodes of banking turmoil do not have an effect on our inferences.

\section{[INSERT TABLE 9: CONFOUNDING EVENTS - BANKING CRISES]}

In response to these banking problems, legislators passed the Financial Institutions Reform, Recovery, and Enforcement Act (FIRREA) in 1989, and the Federal Deposit Insurance Corporation Improvement Act (FDICIA) in 1991.

The FIRREA provided the authorities with the resources to close insolvent S\&L institutions and pay off depositors. This law also amended the process for establishing receivership claims by providing guidelines as to how the receiver has to give notice of the receivership and when and how creditors can file claims with the intention to harmonize the liquidation process, irrespective of whether claims are filed against state banks, nationally-chartered banks, or S\&L associations. However, it did not amend the order of priority in which creditors of a failed institution were paid off.

If FIRREA plays any role for our inferences, removing observations from 1989Q4 to 1993Q2 during which FIRREA was in place should affect the key coefficients. Table 10, Panel A, shows this is not the case.

The FDICIA contained further efforts to increase banking system health. This legislation increased the power of regulators and bolstered the resources of the FDIC. Inter alia, it introduced the least cost resolution provision and guidelines for prompt corrective action. While FDICIA does not prescribe changes to the claims structure in bank liquidations, the mandate to resolve banks at the least cost suggests a direct effect on the key coefficients of interest. Purchase and assumption transactions which tend to be associated with lower resolution costs are easier in states with depositor preference because depositor preference avoids the lobbying for claims as discussed by Hardy (2013). Empirically, this suggests that FDICIA should have resulted in treatment effects that are greater in absolute magnitude via the effect on nationally-chartered banks that did not have depositor preference. In other words, a test of the effects of depositor preference prior to the enactment of FDICIA should result in the same direction of the effects, yet at smaller magnitudes.

To examine this conjecture, we omit observations from 1991Q4 to 1993Q2. The results, shown in Panel B of Table 10, confirm our hypothesis and reinforce our findings.

Another confounding effect is the wave of deregulation which concerns the lifting of restrictions on the geographical scope of bank activities. From the 1970s onwards, 38 states removed restrictions on intrastate branching and allowed bank holding companies (BHCs) to convert subsidiaries into branches. States also permitted de novo branching statewide. Similar to the introduction of state depositor preference laws, the branching deregulation comes about in a staggered manner. Simultaneously, several states also started to deregulate interstate restrictions since the 1970s in a staggered manner, culminating in the Riegle-Neal Interstate Banking Act of 1994 which allowed banks and BHCs to acquire banks and BHCs in other states. The deregulation of inter- and intrastate restrictions markedly changed the competitive landscape in the banking industry, primarily by facilitating cross-border mergers. However, these legislative changes do not affect state and nationally-chartered banks differentially, and they also do not affect the priority structure of claims.

Empirical tests help rule out that the two types of deregulation drive our inferences. In Panel $\mathrm{C}$ of Table 10, we first interact a dummy variable that takes on the value of the dummy for bank charter types with a dummy variable for interstate deregulation which takes on the value of one if a state allowed interstate branching (or zero otherwise), and we then also interact this interaction term with the dummy variable for depositor preference laws. Next, we test for the effect of intrastate deregulation by following the same approach using a dummy variable that takes on the value of one if 
a state also allowed intrastate branching (zero otherwise). The interaction terms remain insignificant, and our main results are unaffected, although the magnitude of the coefficients declines.

\section{[INSERT TABLE 10: CONFOUNDING EVENTS - REGULATION AND DEREGULATION]}

\subsection{Other sensitivity tests}

We first revisit the validity of the parallel trends assumption and present placebo regressions. The intuition is that the changes in conduct we documented can only be observed when depositor preference affects state-chartered banks but they can neither be observed at other points in time, nor can they be observed in other types of banks which are not subject to treatment. Our first set of placebo tests in Panel A of Table 11 randomly assigns placebo treatments to nationally-chartered banks that operate in states where depositor preference was enacted to ensure that the economic environment is comparable. The second set of placebo tests in Panel B focuses on anticipation effects and assigns treatment randomly to state-chartered banks prior to the actual treatment to rule out that banks adjust their behavior in the run up to depositor preference. The placebo tests remain insignificant, showing that our results are not confounded by the reaction within the control group or by anticipation effects.

A key condition for causal inferences is the random assignment of depositor preference laws. Whited and Roberts (2012) argue that the magnitudes of the coefficients in difference-in-difference estimation should remain unaffected irrespective of the inclusion of control variables if treatment can be assumed to be as good as random. Otherwise, random assignment for the treatment variable should be questioned. We replicate our main tests in Panel $\mathrm{C}$ of Table 11 without the time-varying bank-specific control variables, and find the magnitudes of the key coefficients to remain unchanged.

Another set of sensitivity checks deals with serial correlation in the error terms. This is important because Bertrand et al. (2004) demonstrate that difference-in-differences estimators yield spuriously low standard errors leading to over-rejection of the null hypothesis when the dependent variable is serially correlated through time and there are more than two time periods. So far, we clustered heteroskedasticity-adjusted standard errors on the bank level to account for the structure of the serial correlation within each bank in our tests. As an alternative way Panel D collapses the observations before and the observations following enactment of depositor preference into one period at the mean value. This test does not affect our inferences.

Finally, we jointly consider the correlation in the residuals within panels, i.e., across banks, and over time by replicating in Panel E of Table 11 the main regression with double-clustering of the standard errors at the bank and year level as suggested by Thompson (2011). Our results remain unchanged. ${ }^{18}$

\section{[INSERT TABLE 11: FURTHER SENSITIVITY CHECKS]}

\subsection{Falsification test and external validity}

Prior to closing the loop by discussing the external validity of our tests, we present a falsification exercise.

To this end, we run Monte Carlo simulations with 1,000 replications to check whether statechartered banks were affected by federal depositor legislation in 1993. For this test, we constrain the sample to state-chartered banks from the 15 states in our main analyses because a suitable control group does not exist. Next, we randomly assign banks to a placebo treatment that is equal to 1 in 1993Q3 and all subsequent quarters or zero otherwise. We then estimate

$y_{i t}=\alpha+$ Blacebo $_{i t}+X_{i t}^{\prime} \gamma+\varphi_{i}+\varphi_{t}+\varepsilon_{i t}$.

Conditional on quarter-fixed effects, this specification estimates how much higher/lower the dependent variable was within the same bank following the introduction of national depositor preference. Because we know this should have had no effect on state-chartered banks, we know that the null of zero effect is true. We should therefore only reject the null by making Type 1 errors. The

18 In unreported tests, we also considered further alternatives of clustering by state-year and by state-bank-year, but the results remain virtually unchanged. These tests are available upon request. 
results of this exercise are shown in Panel A of Table 12 where we repeat this procedure 1,000 times. The rejection rates for all dependent variables are in line with those that would occur through Type 1 errors. This analysis confirms that state-chartered banks affected by state depositor preference law remained unaffected by the subsequent introduction of national depositor preference.

Finally, we discuss the external validity of our findings. As in any quasi-experiment, a key question is to what extent our findings generalize beyond our economic laboratory. The question of generalizability is of particular importance for Europe where policy makers and the banking industry have been debating the introducing depositor preference for banks in the European Union. ${ }^{19}$

The enactment of national depositor preference following the Omnibus Budget Reconciliation Act of 1993 allows us to inspect whether the results are externally valid. This law stipulated that all banks are henceforth subject to depositor preference.

Provided that state-chartered banks in states that had previously enacted depositor preference were already subject to these provisions, they serve as an ideal control group for an alternative setup using difference-in-differences estimation. ${ }^{20}$ For these tests, we extend the sample period to 1997Q3. The treatment group consists therefore of all banks in states that had not implemented depositor preference law prior to 1993Q3 and nationally-chartered banks in states that had introduced depositor preference legislation. Because we rely on cross-state variation in treatment status to identify the treatment effect, we cannot include state-quarter controls. Panel B of Table 12 presents the results. Using this new treatment, we continue to find the same effect on funding costs as in the main regressions. This test highlights the external validity of our inferences.

\section{[INSERT TABLE 12: FALSIFICATION TEST AND EXTERNAL VALIDITY]}

\section{Summary and conclusion}

This article exploits an unexplored natural experiment to inform the debate about market discipline using a novel approach. We use the staggered introduction of depositor preference legislation which changes the priority of claims on failed banks' assets in 15 U.S. states between 1983 and 1993. The preventative influence of junior debt can be used to establish whether depositors and, more importantly, non-depositors whose claims are subordinated under depositor preference to those of depositors, monitor and influence bank conduct.

The progressive nature of the introduction of depositor preference for state-chartered banks provides a unique opportunity to overcome the usual identification challenges. The plausible exogeneity of these laws with respect to bank behavior which we document in this paper, and the fact that our setting allows comparing state-chartered banks with nationally-chartered banks that operate in the same federal state enable us to establish a causal link between the seniority of debt claims and bank conduct. This issue is of timely importance for policy and regulation.

While Australia, Argentina, Hong Kong, Malaysia, and the U.S. already have some form of depositor preference in place, European policy makers and the banking industry there have engaged in intensive and controversial discussions about assigning priority to depositors' claims in a bank failure. The proponents of such legislation argue depositor preference will increase market discipline exerted by non-deposit claimants, increase bank soundness, and reduce the cost of bank failures. However, the banking industry has lobbied against assigning depositors a priority claim on failed banks' assets. The opponents argue that priority for depositors increases banks' cost of funds as non-deposit claimants seek risk premia that would ultimately undermine soundness.

Our difference-in-difference estimation strategy evaluates these concerns by exploiting within statequarter differences in the reaction of treated and untreated banks. The results highlight that changes in

19 Several media reports and statements by EU policymakers and bankers suggest a lively debate on this matter. While Bloomberg News reports on $8^{\text {th }}$ May 2013 that the "EU sees shocks without bank depositor preference rule", banks in Europe view depositor preference as undesirable. The website thisismoney.co.uk reports that "Banks complain depositor preference plan will raise costs for customers" on $1^{\text {st }}$ June 2012, and Angela Knight, Chief Executive of the British Bankers Association, issued a statement on $13^{\text {th }}$ June 2012 that "' $[\ldots]$ depositor preference proposition may work against financial stability and be a turn off for the investors in a bank".

20 We exclude state-chartered banks from Arizona, Connecticut, Florida, Maine, Minnesota, New Hampshire, and Rhode Island from the control group because these states introduced depositor preference legislation shortly before federal enactment. Excluding these banks ensures that the implied counterfactual is not biased by banks reacting to state depositor preference laws. 
the priority of debt claims give rise to greater monitoring which has wide-ranging implications for the banking sector in terms of funding cost, liability structure, soundness, and profitability.

The key findings based on 199,731 observations for 5,509 banks operating in 15 states in the U.S illustrate that non-depositors are a credible source of market discipline.

While our regressions show that overall funding costs decline, we document that non-deposit funds become more expensive, supporting the idea that depositor preference increases market discipline. The effect is also economically significant. For the average state-chartered bank in the sample, introducing depositor preference increases the costs on non-deposit funds, scaled by total liabilities, by 22 percent. If there are direct pricing effects emerging from the introduction of depositor preference, it is also plausible to expect a corresponding quantity effect for uninsured deposits that should coincide with increased monitoring by non-depositors. This is indeed what we find. The treatment groups' market share of uninsured deposits increases by 13 percent. Importantly, there are no changes to their market share in non-deposits which prompts non-depositors to increase monitoring intensity.

As the changes in monitoring intensity in this paper are plausibly exogenous, our inferences remain intact across a variety of sensitivity checks and falsification exercises. We also show that a series of potential alternative explanations and possibly confounding factors such as regional and nation-wide banking crises, and a wave of deregulation of banking markets cannot be responsible for the results documented in this study.

We are not only able to present evidence of increased monitoring by non-depositors, but also find evidence that the increase in monitoring triggers changes in bank conduct. Our tests that focus on bank conduct examine risk taking. We find that Z-scores (ln) increase, and the non-performing loans ratio, and the leverage ratio decline significantly. For the average bank in the sample, the Z-score (ln) increases by 22 percent. The results from this exercise tie in with theories by Fama (1980, 1985), and Rajan and Winton (1995) that predict an inverse association between seniority of debt claims and debtholders incentives to monitor. To this end, this work reiterates the idea to complement regulatory discipline by harnessing market forces. Important in this context is the fact that our paper is one of a limited number of studies that offer evidence for the influencing dimension of market discipline.

In sum, we interpret our results as supportive evidence for monitoring by junior claimants as a result of the introduction of depositor preference laws. From a policy perspective, our findings therefore justify the proposals put forward in the policy community to introduce depositor preference laws in Europe. However, we temper our summary by pointing out two issues: First, bank business models have undergone changes over the past few decades and the nature of our experimental setting renders it infeasible to use more recent data. Second, we do not claim that depositor preference is a panacea to constrain bank risk taking.

Yet, embedded in a system of effective government supervision of banking institutions, protecting depositors on the one hand and effectively increasing market discipline on the other hand are appealing features of depositor preference legislation that have potential to contribute to improved banking system soundness.

We conclude by pointing out the benefit of capitalizing on this experimental setting. The advantage of the experimental setup lies in the fact that the treatment effects are simply measured as the average difference between state-chartered and nationally-chartered banks operating in the same macroeconomic environment. To that extent, the step-by-step adoption of depositor preference legislation can be considered a useful source of exogenous variation in the monitoring incentives of debtholders for further empirical work. The interaction of other features of the financial safety net with changes in the priority structure of claims on a failed bank's assets appears a promising area for future research. 


\section{References}

Acharya, V., Anginer, D. and Warburton, A.J. (2014) The end of market discipline? Investor expectations of implicit state guarantees, Working Paper. New York University, Stern School of Business

Acharya, V., and and N. Kulkarni (2014) Government guarantees and bank vulnerability during the Financial Crisis of 2007-09: Evidence from an Emerging Market. Working Paper. New York University, Stern School of Business

Admati, A., P. M. DeMarzo, M. Hellwig, and P. Pfleiderer (2013) Fallacies, irrelevant facts, and myths in the discussion of capital regulation: Why bank equity is not expensive. Working Paper. Stanford Graduate School of Business

Ashcraft, A.B. (2008) Does the market discipline banks? New evidence from regulatory capital mix, Journal of Financial Intermediation 17: 543-561.

Avery, R. B., B, Belton, T., M. and Goldberg, M. A. (1988) Market discipline in regulating bank risk: New evidence from the capital markets, Journal of Money, Credit, and Banking 20: 597-610.

Berger, A. N., R. DeYoung, M. J. Flannery, D. Lee, and O. Oztekin (2008) How do large banking organizations manage their capital ratios? Journal of Financial Services Research 34: 123-149.

Bertrand, M., S. Mullainathan, and E. Duflo (2004) How much should we trust differences-indifferences estimates? Quarterly Journal of Economics 119: 249-75.

Billett, M. T., J. A. Garfinkel, and E. S. O’Neal (1998) The cost of market versus regulatory discipline in banking. Journal of Financial Economics 48: 333-358.

Bliss, R.R. and Flannery, M.J. (2000) Market discipline in the governance of U.S. bank holding companies: Monitoring vs. influencing", Federal Reserve Bank of Chicago Working Paper WP-003.

Birchler, U. (2000) Bankruptcy priority for bank deposits. Review of Financial Studies 13: 813-840.

Calderon, C. and Schaeck, K. (forthcoming) The effects of government interventions in the financial sector on banking competition and the evolution of zombie banks, Journal of Financial and Quantitative Analysis.

Cebenoyan, A.S. and Strahan, P.E. (2004) Risk management, capital structure and lending at banks, Journal of Banking and Finance 28: 19-43.

Curtis, C. T. (1992) The status of foreign deposits under the Federal Depositor Preference Law. University of Pennsylvania Journal of International Economic Law 21: 237-271.

Demirguc-Kunt, A. and Huizinga, H. (2010) Bank activity and funding strategies: The impact on risk and returns, Journal of Financial Economics, Vol. 98(3), pp. 626-650.

Fama, E. F. (1980) Banking in the theory of finance. Journal of Monetary Economics 6: 39-57.

Fama, E. F. (1985) What's different about banks? Journal of Monetary Economics 15: 29-39.

Flannery, M. J. (2014) Maintaining adequate bank capital, Journal of Money, Credit and Banking 46: 157-180.

Flannery, M. J. (2010) Stabilizing large financial institutions with contingent capital certificates, CAREFIN Working Paper, Bocconi University

Flannery, M. J. (2001) The faces of "Market Discipline", Journal of Financial Services Research 20: 107-119.

Flannery, M. J. (1998) Using market information in prudential bank supervision: A review of the U.S. empirical evidence. Journal of Money, Credit and Banking 30: 273-305. 
Flannery, M. J. and Rangan, K.P. (2008) What caused the bank capital build-up of the 1990s? Review of Finance 12: 391-429.

Flannery, M. J., and Sorescu, S.S. (1996) Evidence of bank market discipline in subordinated debenture yields: 1983-1991. Journal of Finance 51: 1347-1377.

Froot, K.A. and Stein, J.C. (1998) Risk management, capital budgeting, and capital structure policy for financial institutions: An Integrated Approach, Journal of Financial Economics 47: 55-82.

Gan, J. (2004) Banking market structure and financial stability: Evidence from the Texas real estate crisis in the 1980s, Journal of Financial Economics 73: 567-601

Goldberg, L.G. and Hudgins, S.C. (2002) Depositor discipline and changing strategies for regulating thrift institutions, Journal of Financial Economics 63: 263-274.

Gorton, G. and Santomero, A.M. (1990) Market discipline and bank subordinated debt, Journal of Money, Credit and Banking 22: 119-128.

Gropp, R.E., and Heider, F. (2010) The determinants of bank capital structure. Review of Finance 14: 587-622.

Hardy, D.C. (2013) Bank resolution costs, depositor preference, and asset encumbrance. Working Paper 13/172, International Monetary Fund.

Hirschhorn, E., and Zervos, D. (1990) Policies to change the priority of claimants: The case of depositor preference laws, Journal of Financial Services Research 4: 111-125.

Huang, R. and Ratnovski, L. (2011) The dark side of bank wholesale funding, Journal of Financial Intermediation 20: 248-263.

Krishnan, C.N.V., Ritchken, P.H. and Thomson, J.B. (2005) Monitoring and controlling bank risk: Does risky debt help?, Journal of Finance 60: 343-378.

Kroszner, R.S. and Strahan, P.E. (1999) What drives deregulation? Economics and politics of the relaxation of bank branching restrictions, Quarterly Journal of Economics 114: 1437-1467.

Le Lesle, V. (2012) Bank debt in Europe: Are funding models broken? IMF Working Paper $\mathrm{WP} / 12 / 299$.

Lemmon, M. and Roberts, M.R. (2010) The response of corporate financing and investment to changes in the supply of credit, Journal of Financial and Quantitative Analysis 45: 555-587.

Marino, J.A. and Bennett, R. (1999) The consequences of national depositor preference, FDIC Banking Review 12, no. 2:19-38.

Martinez Peria, M.S. and Schmukler, S. (2001) Do depositors punish banks for bad behavior? Market discipline, deposit insurance, and banking crises, Journal of Finance 56: 1029-1051.

Osterberg, W.P. (1996) The impact of depositor preference laws, Federal Reserve Bank of Cleveland Economic Review, Vol. Q3, pp. 2-11.

Osterberg, W.P. and Thomson, J.B. (1999) Depositor preference laws and the cost of debt capital, Federal Reserve Bank of Cleveland Economic Review, Vol. Q3, pp. 10-20.

Peura, S. and Keppo, J. (2006) Optimal bank capital with costly recapitalization, Journal of Business 79: 2163-2202

Rajan, R., and Winton, A. (1995) Covenants and collateral as incentives to monitor, Journal of Finance 50: 1113-1146.

Rosen, R.J. (2005) Switching primary federal regulators: Is it beneficial for U.S. banks? Federal Reserve Bank of Chicago Economic Perspectives, Vol. 29(Q3), pp. 16-33.

Strahan, P.E. (2003) The real effects of U.S. banking deregulation, Federal Reserve Bank of St. Louis Review. 
Thompson (2011) Simple formulas for standard errors that cluster by both firm and time, Journal of Financial Economics 99: 1-10.

Whited, T. R., and M. R. Roberts (2012) Endogeneity in empirical corporate finance, in: G. Constantinides, M. Harris, and R. Stulz, eds. Handbook of the Economics of Finance Volume 2, 2012 
Table 1

The Political Economy of Depositor Preference Adoption

\begin{tabular}{|c|c|c|c|}
\hline \multicolumn{4}{|c|}{ Panel A: Depositor preference law States and Date of Implementation } \\
\hline State & Date Effective & In Sample & Observations \\
\hline Alaska & $10 / 15 / 1978$ & No & \\
\hline Arizona & $9 / 21 / 1991$ & Yes & 1,211 \\
\hline California & $6 / 27 / 1986$ & Yes & 16,433 \\
\hline Colorado & $5 / 1 / 1987$ & Yes & 15,811 \\
\hline Connecticut & $5 / 22 / 1991$ & Yes & 3,936 \\
\hline Florida & $7 / 3 / 1992$ & Yes & 12,960 \\
\hline Georgia & $1974 *$ & No & \\
\hline Hawaii & $6 / 24 / 1987$ & Yes & 410 \\
\hline Idaho & $1979 * *$ & No & \\
\hline Indiana & 1943 & No & \\
\hline Iowa & $1 / 1 / 1970$ & No & \\
\hline Kansas & $7 / 1 / 1985$ & Yes & 23,386 \\
\hline Louisiana & $1 / 1 / 1985$ & Yes & 10,255 \\
\hline Maine & $4 / 16 / 1991$ & Yes & 1,472 \\
\hline Minnesota & $4 / 24 / 1990$ & Yes & 25,431 \\
\hline Missouri & $5 / 15 / 1986$ & Yes & 23,263 \\
\hline Montana & 1927 & No & \\
\hline Nebraska & 1909 & No & \\
\hline New Hampshire & $6 / 10 / 1991$ & Yes & 1,863 \\
\hline New Mexico & $6 / 30 / 1963$ & No & \\
\hline North Dakota & $7 / 1 / 1987$ & Yes & 6,496 \\
\hline Oklahoma & $5 / 26 / 1965$ & No & \\
\hline Oregon & $1 / 1 / 1974$ & No & \\
\hline Rhode Island & 2/8/1991 & Yes & 482 \\
\hline South Dakota & $7 / 1 / 1969$ & No & \\
\hline Tennessee & 1969 & No & \\
\hline Texas & $8 / 26 / 1985 * * *$ & Yes & 58,890 \\
\hline Utah & 1983 & No & \\
\hline Virginia & $7 / 1 / 1983$ & No & \\
\hline West Virginia & $5 / 11 / 1981$ & No & \\
\hline
\end{tabular}

Panel B: Political economy of enacting depositor preference laws

\begin{tabular}{|c|c|c|c|c|}
\hline \multicolumn{5}{|c|}{ Dependent variable: Depositor preference law } \\
\hline State-chartered assets & $\begin{array}{c}-0.2461 \\
(-0.47)\end{array}$ & & & $\begin{array}{c}-0.2675 \\
(-0.53)\end{array}$ \\
\hline S\&L crisis & & $\begin{array}{c}0.5110 \\
(1.25)\end{array}$ & & $\begin{array}{c}0.4901 \\
(1.18)\end{array}$ \\
\hline Assets in all failed banks & & $\begin{array}{c}0.0013 \\
(1.15)\end{array}$ & & $\begin{array}{c}0.0013 \\
(1.10)\end{array}$ \\
\hline Bank profitability & & $\begin{array}{c}0.0365 \\
(0.61)\end{array}$ & & $\begin{array}{c}0.0330 \\
(0.53)\end{array}$ \\
\hline Democrat governor & & & $\begin{array}{c}-0.0392 \\
(-0.82)\end{array}$ & $\begin{array}{c}-0.0361 \\
(-0.77)\end{array}$ \\
\hline State FE & YES & YES & YES & YES \\
\hline Quarter FE & YES & YES & YES & YES \\
\hline Observations & 2,056 & 2,056 & 2,056 & 2,056 \\
\hline $\mathrm{R}^{2}$ & 0.8080 & 0.8100 & 0.8083 & 0.8112 \\
\hline \multicolumn{5}{|c|}{ Panel C: Treatment and control group in quarter prior to depositor preference } \\
\hline & Treatment & Control & Difference & $t$-Statistic \\
\hline Total interest expenses & 0.0145 & 0.0141 & -0.0003 & -0.31 \\
\hline Interest on deposits & 0.0146 & 0.0141 & -0.0005 & -0.46 \\
\hline Interest on non-deposits & 0.0069 & 0.0086 & 0.0017 & 1.56 \\
\hline Bank size & 11.0949 & 11.3033 & 0.2085 & 0.53 \\
\hline Equity & -0.2645 & -2.8834 & -0.2589 & -1.21 \\
\hline \multicolumn{5}{|c|}{$\begin{array}{l}\text { Notes: This table presents in Panel A the date depositor preference law passed into law in each state. The } \\
\text { information is taken from Marino and Bennett (1999). * indicates that the legislation became effective on } \\
\text { either January } 1 \text { or July } 1 \text {. ** indicates passed by both houses on July } 1 \text {, but that enactment date is unclear. } \\
\text { Where only the year is indicated, neither the month nor the day of enactment is available. *** Texas } \\
\text { amended its law in } 1993 \mathrm{Q} 2 \text { and did not have depositor preference until national depositor preference was } \\
\text { enacted in August } 1993 \text {. Utah enacted depositor preference law legislation during 1983Q1. Panel B shows } \\
\text { the results of linear probability models examining the reasons for the introduction of depositor preference } \\
\text { laws. We estimate the model } D P L_{s t}=\alpha+\beta X_{s t}+\gamma_{s}+\gamma_{t}+\varepsilon_{s t} \text { where } D P L_{s t} \text { is a dummy equal to } 1 \text { if } \\
\text { depositor preference is in force, } X_{s t} \text { is a vector containing private-interest (the ratio of state-chartered assets } \\
\text { to total bank assets), public-interest (the } \mathrm{S} \& \mathrm{~L} \text { crisis, the natural logarithm of failed banks' assets in the state, } \\
\text { mean profitability (ROA) of banks in the state), and political-interest (democratic governor) variables. } t \text { - } \\
\text { statistics are reported in parentheses and standard errors are clustered at the state level. Panel C shows } \\
\text { differences in means between treatment and control group for the key variables of interest and the } \\
\text { associated } t \text {-statistics. } * * * p<0.01 \text {, } * * \mathrm{p}<0.05, * \mathrm{p}<0.1\end{array}$} \\
\hline
\end{tabular}


Table 2

Exogeneity Tests: Cox Proportional Hazards Model

\begin{tabular}{|c|c|c|c|c|c|c|}
\hline & $\begin{array}{c}\text { Total liabilities } \\
\text { expenses }\end{array}$ & $\begin{array}{l}\text { Expenses on } \\
\text { deposits }\end{array}$ & $\begin{array}{l}\text { Expenses on non- } \\
\text { deposits }\end{array}$ & $\begin{array}{l}\text { Insured deposits } \\
\text { market share }\end{array}$ & $\begin{array}{c}\text { Uninsured } \\
\text { deposits market } \\
\text { share }\end{array}$ & $\begin{array}{l}\text { Non-deposits } \\
\text { market share }\end{array}$ \\
\hline Coefficient & 1 & 1 & 1 & 1 & 1.001 & 1 \\
\hline Z-stat & $(0.99)$ & $(1.27)$ & $(0.34)$ & $(0.86)$ & $(0.93)$ & $(0.35)$ \\
\hline Controls & YES & YES & YES & YES & YES & YES \\
\hline State FE & YES & YES & YES & YES & YES & YES \\
\hline Year FE & YES & YES & YES & YES & YES & YES \\
\hline \multirow[t]{2}{*}{ Observations } & 1196 & 1196 & 1196 & 1196 & 1196 & 1196 \\
\hline & $\begin{array}{c}\text { Z-score } \\
(\ln )\end{array}$ & $\begin{array}{c}\text { Non-performing } \\
\text { loans }\end{array}$ & $\begin{array}{c}\text { Leverage } \\
\text { Ratio }\end{array}$ & $\begin{array}{l}\text { Return on assets } \\
(\ln )\end{array}$ & $\begin{array}{l}\text { Return on equity } \\
(\ln )\end{array}$ & $\begin{array}{c}\text { Interest income } \\
(\ln )\end{array}$ \\
\hline Coefficient & 3.177 & 1.376 & 1.001 & 2.565 & 0.618 & 1.622 \\
\hline Z-stat & $(1.37)$ & (1.64) & $(0.89)$ & $(0.39)$ & $(-0.37)$ & (1.19) \\
\hline Controls & YES & YES & YES & YES & YES & YES \\
\hline State FE & YES & YES & YES & YES & YES & YES \\
\hline Year FE & YES & YES & YES & YES & YES & YES \\
\hline Observations & 1196 & 1196 & 1196 & 1196 & 1196 & 1196 \\
\hline \multicolumn{7}{|c|}{$\begin{array}{l}\text { Notes. This table presents Cox proportional hazard (Cox PH) models to verify that adoption of depositor preference law is exogenous with respect to } \\
\text { banks' costs of funds, liability structure and health. In the Cox proportional hazard models, the dependent variable is equal to } 1 \text { if depositor preference } \\
\text { law has been enacted, } 0 \text { otherwise. The main explanatory variables include totals of interest expenses, interest expenses on deposits, interest expenses on } \\
\text { non-deposits, liabilities, deposits, non-deposits, the Z-score, non-performing loans, the leverage ratio, return on equity, interest income, total loans, of all } \\
\text { banks operating in the state. A state is dropped from the analysis in the quarter after it adopts depositor preference law. The vector of control variables } \\
\text { includes the amount of failed banks' deposits, estimated losses resulting from bank failures, number of bank failures, the concentration ratio of bank } \\
\text { deposits (log of HHI), the ratio of total bank assets to GDP, and the logarithm of the unemployment rate. All control variables are aggregated at the state } \\
\text { level. State and year dummies are included. Robust } \mathrm{z} \text {-statistics are reported in parentheses. } * * * \mathrm{p}<0.01, * * \mathrm{p}<0.05 \text {, } * \text { p }<0.1 \text {. Standard errors are clustered } \\
\text { on the state level. }\end{array}$} \\
\hline
\end{tabular}


Table 3

Summary Statistics and Representativeness

\begin{tabular}{|c|c|c|c|c|c|}
\hline \multicolumn{6}{|l|}{ Panel A: Summary Statistics } \\
\hline Variable & $N$ & Mean & $S D$ & Min & $\operatorname{Max}$ \\
\hline Total interest expenses & 199,698 & 1.420 & 0.423 & 0.509 & 7.745 \\
\hline Interest expenses on deposits & 199,698 & 1.430 & 0.434 & 0.297 & 7.797 \\
\hline Interest expenses on non-deposits & 199,698 & 0.635 & 1.225 & 0 & 13.084 \\
\hline Total liabilities & 199,698 & 0.913 & 0.033 & 0.763 & 0.975 \\
\hline Total domestic deposits & 199,698 & 0.973 & 0.040 & 0.713 & 0.999 \\
\hline Total non-deposits & 199,698 & 0.027 & 0.040 & 0.001 & 0.286 \\
\hline Insured deposits & 199,698 & 0.932 & 0.088 & 0.501 & 0.998 \\
\hline Market share of insured deposits & 199,698 & 0.000 & 0.000 & 0 & 0.001 \\
\hline Uninsured deposits & 199,698 & 0.039 & 0.070 & 0 & 0.331 \\
\hline Market share of uninsured deposits & 199,698 & 0.001 & 0.002 & 0 & 0.024 \\
\hline Zscore $(\ln )$ & 199,698 & 1.351 & 4.887 & -6.908 & 10.618 \\
\hline Standard deviation of ROA (ln) & 199,698 & -6.685 & 0.839 & -12.714 & -2.124 \\
\hline Standard deviation of ROA & 199,698 & 0.002 & 0.003 & 0.000 & 0.119 \\
\hline Return on assets (ln) & 199,698 & -6.129 & 0.782 & -12.619 & -1.506 \\
\hline Return on assets & 199,698 & 0.003 & 0.003 & 0.000 & 0.222 \\
\hline Equity to total assets (ln) & 199,698 & -2.588 & 0.721 & -9.968 & -0.047 \\
\hline Equity to total assets & 199,698 & 0.085 & 0.034 & 0.001 & 0.234 \\
\hline Non-performing loans to total loans & 199,698 & 0.017 & 0.023 & 0 & 0.107 \\
\hline Leverage ratio (Debt to equity ratio) & 199,698 & 11.645 & 4.849 & 0 & 30.985 \\
\hline Return on equity $(\ln )$ & 199,698 & -4.394 & 1.802 & -9.399 & 4.984 \\
\hline Return on equity & 199,698 & 0.039 & 0.489 & 0.000 & 146.000 \\
\hline Total interest income to total loans (ln) & 199,698 & -3.486 & 1.204 & -6.908 & 6.535 \\
\hline Total interest income to total loans & 199,698 & 0.043 & 0.022 & 0.001 & 0.128 \\
\hline Treatment*Charter & 199,698 & 0.369 & 0.483 & 0 & 1 \\
\hline Bank size $(\ln )$ & 199,698 & 10.635 & 1.183 & 5.649 & 18.591 \\
\hline Total assets & 199,698 & 108969.1 & 324164.4 & 4825 & 3130040 \\
\hline \multicolumn{6}{|l|}{ Panel B: Sample representativeness } \\
\hline & \multicolumn{2}{|c|}{$\begin{array}{c}\text { Banks in treatment state } \\
\text { vs. Banks in all other states }\end{array}$} & \multicolumn{3}{|c|}{$\begin{array}{l}\text { Banks in treatment state } \\
\text { vs. Banks in all other states } \\
\text { (including states with depositor } \\
\text { preference prior to 1984) }\end{array}$} \\
\hline Variable & $\begin{array}{c}\text { Difference } \\
\text { Means }\end{array}$ & $\begin{array}{l}\text { Wilcoxon } \\
\text { p-value }\end{array}$ & $\begin{array}{r}\text { Differ } \\
\text { mea }\end{array}$ & & $\begin{array}{c}\text { Wilcoxon } \\
\text { p-value }\end{array}$ \\
\hline Total interest expenses & 0.000 & 0.961 & 0.00 & & 0.741 \\
\hline Interest expenses on deposits & 0.000 & 0.936 & 0.00 & & 0.804 \\
\hline Interest expenses on non-deposits & 0.000 & 0.619 & 0.00 & & 0.984 \\
\hline Total liabilities & -0.009 & 0.052 & -0.0 & & 0.052 \\
\hline Total domestic deposits & -0.009 & 0.328 & -0.0 & & 0.535 \\
\hline Total non-deposits & 0.009 & 0.312 & 0.00 & & 0.535 \\
\hline Zscore (ln) & 0.372 & 0.183 & 0.34 & & 0.193 \\
\hline Non-performing loans to total loans & $-0.005 * * *$ & 0.001 & -0.0 & & 0.045 \\
\hline Leverage ratio (Debt to equity ratio) & $-1.093 *$ & 0.028 & -0.76 & & 0.041 \\
\hline Return on assets $(\ln )$ & 0.069 & 0.026 & 0.08 & & 0.005 \\
\hline Return on equity (ln) & 0.018 & 0.183 & 0.08 & & 0.066 \\
\hline Total interest income to total loans $(\ln )$ & 0.028 & 0.936 & 0.03 & & 0.984 \\
\hline
\end{tabular}

Notes: Panel A presents summary statistics on all variables used throughout the paper. Panel B tests for representativeness between the banks in the 15-state sample and all other banks in the U.S. in 1993. 
Table 4

Parallel Trends Tests

\begin{tabular}{|c|c|c|c|c|c|c|c|c|}
\hline \multirow[b]{2}{*}{ Variable } & \multicolumn{2}{|c|}{$t-1$ to $t-3$} & \multicolumn{2}{|c|}{$t-1$} & \multicolumn{2}{|c|}{$t-2$} & \multicolumn{2}{|c|}{$t-3$} \\
\hline & Difference & $\begin{array}{l}\text { Wilcoxon } \\
\text { p-value }\end{array}$ & Difference & $\begin{array}{c}\text { Wilcoxon } \\
\text { p-value }\end{array}$ & Difference & $\begin{array}{c}\text { Wilcoxon } \\
\text { p-value }\end{array}$ & Difference & $\begin{array}{l}\text { Wilcoxon } \\
\text { p-value }\end{array}$ \\
\hline$\Delta$ Total interest expenses & -0.002 & 0.702 & -0.003 & 0.819 & 0.001 & 0.788 & -0.005 & 0.724 \\
\hline$\Delta$ Interest expenses on deposits & 0.000 & 0.945 & 0.000 & 0.984 & -0.001 & 0.756 & 0.002 & 0.984 \\
\hline$\Delta$ Interest expenses on non-deposits & -0.015 & 0.984 & 0.047 & 0.724 & -0.122 & 0.468 & 0.031 & 0.724 \\
\hline$\Delta$ Insured deposits market share & 0.002 & 0.193 & -0.009 & 0.191 & 0.004 & 0.141 & $0.020 * *$ & 0.011 \\
\hline$\Delta$ Uninsured deposits market share & 0.004 & 0.869 & -0.006 & 0.439 & 0.032 & 0.758 & 0.002 & 0.917 \\
\hline$\Delta$ Non-deposits market share & -0.005 & 0.467 & 0.018 & 0.917 & -0.025 & 0.633 & 0.005 & 0.443 \\
\hline$\Delta$ Insured deposits & 0.008 & 0.581 & -0.006 & 0.663 & 0.002 & 0.443 & 0.029 & 0.395 \\
\hline$\Delta$ Market share of insured deposits & 0.011 & 0.707 & -0.003 & 0.373 & 0.028 & 0.468 & 0.008 & 0.373 \\
\hline$\Delta$ Uninsured deposits & 0.000 & 0.977 & -0.029 & 0.439 & 0.056 & 0.758 & -0.023 & 0.917 \\
\hline$\Delta$ Market share of uninsured deposits & -0.001 & 0.884 & -0.048 & 0.439 & 0.059 & 0.999 & -0.024 & 0.917 \\
\hline$\Delta$ Zscore $(\ln )$ & -0.128 & 0.308 & -0.072 & 0.263 & -0.251 & 0.867 & -0.061 & 0.901 \\
\hline$\Delta$ Non-performing loans to total loans & 0.552 & 0.977 & 0.239 & 0.513 & 0.002 & 0.541 & 1.366 & 0.600 \\
\hline$\Delta$ Leverage ratio (Debt to equity ratio) & 0.001 & 0.818 & -0.023 & 0.548 & -0.002 & 0.951 & 0.026 & 0.272 \\
\hline$\Delta$ Return on equity $(\ln )$ & -0.003 & 0.268 & 0.001 & 0.967 & -0.032 & 0.279 & 0.021 & 0.169 \\
\hline$\Delta$ Total interest income to total loans $(\ln )$ & 0.002 & 0.501 & 0.007 & 0.101 & 0.001 & 0.885 & -0.003 & 0.885 \\
\hline
\end{tabular}


Table 5

Pricing effects of depositor preference: Funding Costs

\begin{tabular}{|c|c|c|c|c|c|c|c|c|c|c|c|c|}
\hline \multirow[b]{2}{*}{ Dependent variable } & \multicolumn{9}{|c|}{ Panel A: All states } & \multicolumn{3}{|c|}{ Panel B: 15 states } \\
\hline & $\begin{array}{c}\begin{array}{c}\text { Total interest } \\
\text { expenses }\end{array} \\
\end{array}$ & $\begin{array}{c}\text { Interest on } \\
\text { deposits }\end{array}$ & $\begin{array}{c}\text { Interest on } \\
\text { non-deposits }\end{array}$ & $\begin{array}{c}\begin{array}{c}\text { Total interest } \\
\text { expenses }\end{array} \\
\end{array}$ & $\begin{array}{c}\text { Interest on } \\
\text { deposits }\end{array}$ & $\begin{array}{c}\text { Interest on } \\
\text { non-deposits }\end{array}$ & $\begin{array}{c}\begin{array}{c}\text { Total interest } \\
\text { expenses }\end{array} \\
\end{array}$ & $\begin{array}{c}\text { Interest on } \\
\text { deposits }\end{array}$ & $\begin{array}{c}\text { Interest on } \\
\text { non-deposits }\end{array}$ & $\begin{array}{c}\text { Total interest } \\
\text { expenses }\end{array}$ & $\begin{array}{c}\begin{array}{c}\text { Interest on } \\
\text { deposits }\end{array} \\
\end{array}$ & $\begin{array}{c}\text { Interest on } \\
\text { non-deposits }\end{array}$ \\
\hline Charter & $\begin{array}{c}0.0444 * * * \\
(13.47)\end{array}$ & $\begin{array}{c}0.0516^{* * * *} \\
(14.53)\end{array}$ & $\begin{array}{c}-0.2075^{* * * *} \\
(-16.53)\end{array}$ & $\begin{array}{c}0.0498 * * * \\
(14.20)\end{array}$ & $\begin{array}{c}0.0535^{* * * *} \\
(14.22)\end{array}$ & $\begin{array}{c}-0.0877 * * * \\
(-7.78)\end{array}$ & $\begin{array}{l}0.0077 \\
(0.97)\end{array}$ & $\begin{array}{l}0.0120 \\
(1.43)\end{array}$ & $\begin{array}{c}-0.0136 \\
(-0.41)\end{array}$ & $\begin{array}{l}0.0169 \\
(1.38)\end{array}$ & $\begin{array}{l}0.0195 \\
(1.52)\end{array}$ & $\begin{array}{c}-0.0822 \\
(-1.39)\end{array}$ \\
\hline DPL & $\begin{array}{c}0.0412 * * * \\
(9.10)\end{array}$ & $\begin{array}{c}0.0457^{* * * *} \\
(9.77)\end{array}$ & $\begin{array}{c}-0.1418^{* * * *} \\
(-8.47)\end{array}$ & $\begin{array}{c}0.0338 * * * \\
(7.40)\end{array}$ & $\begin{array}{c}0.0374 * * * \\
(7.87)\end{array}$ & $\begin{array}{c}-0.1162^{* * * *} \\
(-7.42)\end{array}$ & & & & & & \\
\hline Charter*DPL & $\begin{array}{c}-0.0418 \text { **** } \\
(-8.50)\end{array}$ & $\begin{array}{c}-0.0458 * * * * \\
(-8.48)\end{array}$ & $\begin{array}{c}0.1515 * * * \\
(7.81)\end{array}$ & $\begin{array}{c}-0.0403^{* * * *} *{ }^{-8.13)}\end{array}$ & $\begin{array}{c}-0.0433 * * * * \\
(-7.95)\end{array}$ & $\begin{array}{c}0.1186^{* * * *} \\
(6.86)\end{array}$ & $\begin{array}{c}-0.0169 * * * \\
(-3.62)\end{array}$ & $\begin{array}{c}-0.0196 * * * \\
(-4.16)\end{array}$ & $\begin{array}{c}0.1214 * * * \\
(6.30)\end{array}$ & $\begin{array}{c}-0.0192 * * * \\
(-4.06)\end{array}$ & $\begin{array}{c}-0.0219 * * * \\
(-4.56)\end{array}$ & $\begin{array}{c}0.1388^{* * * *} \\
(6.31)\end{array}$ \\
\hline Bank size & & & & $\begin{array}{c}0.0075^{* * * *} \\
(4.48)\end{array}$ & $\begin{array}{r}0.0017 \\
(0.89)\end{array}$ & $\begin{array}{c}0.2068 * * * \\
(47.23)\end{array}$ & $\begin{array}{c}0.1384 * * * \\
(18.75)\end{array}$ & $\begin{array}{c}0.1415 * * * \\
(18.51)\end{array}$ & $\begin{array}{c}0.0690 * * * \\
(4.80)\end{array}$ & $\begin{array}{c}0.1490 * * * \\
(12.29)\end{array}$ & $\begin{array}{c}0.1585^{* * * *} \\
(13.14)\end{array}$ & $\begin{array}{c}0.0897^{* * * *} \\
(3.47)\end{array}$ \\
\hline Capital ratio & & & & $\begin{array}{c}-0.0125 * * * \\
(-4.30)\end{array}$ & $\begin{array}{c}-0.0101 * * \\
(-2.39)\end{array}$ & $\begin{array}{c}-0.0560 * * * \\
(-8.00)\end{array}$ & $\begin{array}{c}-0.0521 * * * \\
(-16.86)\end{array}$ & $\begin{array}{c}-0.0540 * * * \\
(-16.75)\end{array}$ & $\begin{array}{c}0.0082 \\
(1.19)\end{array}$ & $\begin{array}{c}-0.0347 * * * \\
(-11.33)\end{array}$ & $\begin{array}{c}-0.0373 * * * \\
(-10.83)\end{array}$ & $\begin{array}{c}0.0249 * * \\
(2.31)\end{array}$ \\
\hline S\&L crisis & & & & $\begin{array}{c}0.1693 * * * \\
(16.62)\end{array}$ & $\begin{array}{c}0.1843^{* * * *} \\
(17.60)\end{array}$ & $\begin{array}{c}-0.2160 * * * \\
\quad(-4.24)\end{array}$ & & & & & & \\
\hline Interstate deregulation & & & & $\begin{array}{c}0.0459 * * * \\
(11.07)\end{array}$ & $\begin{array}{c}0.0463^{* * * *} \\
(10.87)\end{array}$ & $\begin{array}{c}-0.0113 \\
(-1.39)\end{array}$ & & & & & & \\
\hline Interstate deregulation & & & & $\begin{array}{c}-0.0095 * * * \\
(-3.34) \\
\end{array}$ & $\begin{array}{c}-0.0082^{* * * *} \\
(-2.79)\end{array}$ & $\begin{array}{c}-0.0413 * * * * \\
(-4.94)\end{array}$ & & & & & & \\
\hline State FE & YES & YES & YES & YES & YES & YES & & & & & & \\
\hline Quarter FE & YES & YES & YES & YES & YES & YES & & & & & & \\
\hline Bank FE & & & & & & & YES & YES & YES & YES & YES & YES \\
\hline State*Quarter FE & & & & & & & YES & YES & YES & YES & YES & YES \\
\hline Observations & 528,522 & 528,522 & 528,522 & 528,522 & 528,522 & 528,522 & 528,522 & 528,522 & 528,522 & 199,731 & 199,731 & 199,731 \\
\hline $\mathrm{R}^{2}$ & 0.4849 & 0.4710 & 0.0395 & 0.4871 & 0.4725 & 0.0832 & 0.7041 & 0.7040 & 0.3512 & 0.6797 & 0.6855 & 0.0271 \\
\hline Number of banks & 15,392 & 15,392 & 15,392 & 15,392 & 15,392 & 15,392 & 15,392 & 15,392 & 15,392 & 5,509 & 5,509 & 5,509 \\
\hline
\end{tabular}


Table 6

Quantity effects and long-run effects of depositor preference

\begin{tabular}{|c|c|c|c|}
\hline \multicolumn{4}{|c|}{ Panel A: Quantity effects in terms of market shares } \\
\hline Dependent variable & Insured deposits & Uninsured deposits & Non-deposits \\
\hline Charter*DPL & $\begin{array}{l}-0.0080 \\
(-0.35)\end{array}$ & $\begin{array}{c}0.1305^{* * *} \\
(2.26)\end{array}$ & $\begin{array}{l}0.0172 \\
(0.27)\end{array}$ \\
\hline Bank size & $\begin{array}{c}-0.0819 \\
(-1.51)\end{array}$ & $\begin{array}{c}-0.0388 \\
(-1.14)\end{array}$ & $\begin{array}{c}0.1385 \\
(1.75)\end{array}$ \\
\hline Capital ratio & $\begin{array}{c}-0.0058 \\
(-0.31)\end{array}$ & $\begin{array}{c}-0.0312 \\
(-0.48)\end{array}$ & $\begin{array}{c}-0.0198 \\
(-0.32)\end{array}$ \\
\hline State-charter FE & YES & YES & YES \\
\hline State*Quarter FE & YES & YES & YES \\
\hline Observations & 1,286 & 1,286 & 1,286 \\
\hline $\mathrm{R}^{2}$ & 0.0959 & 0.8396 & 0.0416 \\
\hline Number of state-charters & 30 & 30 & 30 \\
\hline \multicolumn{4}{|c|}{ Panel B: Long-run effects of depositor preference laws } \\
\hline Dependent variable & Total interest expenses & Interest on deposits & Interest on non-deposits \\
\hline Charter & $\begin{array}{c}0.0486^{* * *} \\
(3.27)\end{array}$ & $\begin{array}{c}0.0515^{* * * *} \\
(3.30)\end{array}$ & $\begin{array}{c}-0.1163 * * \\
(-1.99)\end{array}$ \\
\hline Charter * post quarter 0 & $\begin{array}{c}-0.0571 * * * \\
(-7.92)\end{array}$ & $\begin{array}{c}-0.0587 * * * \\
(-7.95)\end{array}$ & $\begin{array}{c}0.0271 \\
(0.75)\end{array}$ \\
\hline Charter * post quarter 1 & $\begin{array}{c}-0.0555^{* * * *} \\
(-7.77)\end{array}$ & $\begin{array}{c}-0.0595 * * * \\
(-7.54)\end{array}$ & $\begin{array}{c}0.0789 * * \\
(2.10)\end{array}$ \\
\hline Charter * post quarter2 & $\begin{array}{c}-0.0722 * * * \\
(-9.82)\end{array}$ & $\begin{array}{c}-0.0758 * * * \\
(-10.03)\end{array}$ & $\begin{array}{c}0.1073^{* * * *} \\
(3.19)\end{array}$ \\
\hline Charter * post quarter 3 & $\begin{array}{c}-0.0759 * * * \\
(-11.07)\end{array}$ & $\begin{array}{c}-0.0803 * * * \\
(-11.36)\end{array}$ & $\begin{array}{c}0.1751^{* * * *} \\
(5.90)\end{array}$ \\
\hline Charter * post quarter 4 & $\begin{array}{c}-0.0717 * * * \\
(-10.45)\end{array}$ & $\begin{array}{c}-0.0763 * * * \\
(-10.99)\end{array}$ & $\begin{array}{c}0.1370 * * * \\
(3.99)\end{array}$ \\
\hline Charter * post quarter 5 & $\begin{array}{c}-0.0550 * * * \\
(-7.28)\end{array}$ & $\begin{array}{c}-0.0587 * * * \\
(-7.77)\end{array}$ & $\begin{array}{c}0.1148^{* * * *} \\
(3.11)\end{array}$ \\
\hline Charter $*$ post quarter 6 & $\begin{array}{c}-0.0693 * * * \\
(-9.47)\end{array}$ & $\begin{array}{c}-0.0708^{* * * *} \\
(-9.37)\end{array}$ & $\begin{array}{c}0.1534 * * * \\
(4.61)\end{array}$ \\
\hline Charter * post quarter7 & $\begin{array}{c}-0.0863 * * * \\
(-11.12)\end{array}$ & $\begin{array}{c}-0.0891 * * * \\
(-11.17)\end{array}$ & $\begin{array}{c}0.1062^{* * * *} \\
(3.28)\end{array}$ \\
\hline Charter * post quarter8 & $\begin{array}{c}-0.1164 * * * \\
(-13.63)\end{array}$ & $\begin{array}{c}-0.1197 * * * \\
(-13.78)\end{array}$ & $\begin{array}{c}0.1152^{* * * *} \\
(3.48)\end{array}$ \\
\hline Charter $*$ post quarter 9 & $\begin{array}{c}-0.1218 * * * \\
(-16.20)\end{array}$ & $\begin{array}{c}-0.1255^{* * *} * \\
(-15.87)\end{array}$ & $\begin{array}{c}0.1682 * * * \\
\quad(5.67)\end{array}$ \\
\hline Bank size & $\begin{array}{c}-0.1152 * * * \\
(-17.34)\end{array}$ & $\begin{array}{c}-0.1245^{* * * *} \\
(-18.29)\end{array}$ & $\begin{array}{c}0.2126^{* * * *} \\
(11.49)\end{array}$ \\
\hline Capital ratio & $\begin{array}{c}-0.0994 * * * \\
(-21.65) \\
\end{array}$ & $\begin{array}{c}-0.1074 * * * \\
(-21.56) \\
\end{array}$ & $\begin{array}{c}0.0822 * * * \\
(7.27)\end{array}$ \\
\hline Bank FE & YES & YES & YES \\
\hline State*Quarter FE & YES & YES & YES \\
\hline Observations & 258,594 & 258,594 & 258,594 \\
\hline R2 & 0.5313 & 0.5448 & 0.1583 \\
\hline Number of banks & 5,509 & 5,509 & 5,509 \\
\hline
\end{tabular}

Notes. This table presents in Panel A results of difference-in-difference regressions examining the effect of state depositor preference law enactment on banks' market share on the state level for insured, uninsured deposits, and non-deposits. We estimate $y_{i s t}=\alpha+\beta D P L_{s t} *$ Charter $_{i}+\delta X_{i s t}+\gamma_{i}+\gamma_{s t}+\varepsilon_{i s t}$, where $y$ denotes dependent variable of bank charter $i$ (state or national charter) in state $s$ at time $t$, which includes: the market share of insured deposits, the market share of uninsured deposits, and the market share of non-deposits. The main explanatory variable is an interaction between the depositor preference law and Charter dummy variables. $D P L_{s t}$ is a dummy variable equal to 1 for all banks in states and years following introduction of state depositor preference law, and 0 otherwise; Charter $r_{i}$ is a dummy variable equal to 1 for state-chartered banks, and 0 for nationally-chartered institutions. The coefficient $\beta$ provides information about the effect of state depositor preference law adoption. The set of bank-time varying control variables $X_{\text {ist }}$ include the logarithm of mean banks' total assets (Bank size), and the mean ratio of equity capital to total assets (Capital ratio). Additionally, the regressions include state-quarter-fixed effects $\left(\gamma_{s t}\right)$ and charter-fixed effects $\left(\gamma_{i}\right)$. Panel $\mathrm{B}$ presents the results of difference-in-difference regressions examining the long-run effect of state depositor preference law enactment on banks' costs of funds. We estimate $y_{i s t}=\alpha+\sum_{j=0}^{j=9} \beta_{j}$ Charter $_{i} *$ post quarter $_{j}+\delta X_{i s t}+\gamma_{i}+\gamma_{s t}+\varepsilon_{i s t}$, where $y$ denotes the dependent variable of bank $i$ in state $s$ at time $t$, which include ratios of: total interest expenses to total liabilities (Total interest expenses), interest on deposits to total deposits (Interest on deposits), and interest on other non-deposits to total other nondeposits (Interest on non-deposits). The main explanatory variable is an interaction between the depositor preference law dummy and Charter dummy variable. post quarter $_{j}$ where $j=\in(1, \ldots, 8)$ is a dummy variable equal to 1 for each quarter after enactment of depositor preference in state $s . j=0$ denotes the quarter of enactment. $j=9$ denotes all quarters two years after the date of enactment. Charter $r_{i}$ is a dummy variable equal to 1 for all state-chartered banks, and 0 for nationally-chartered institutions. The coefficient $\beta_{j}$ provides information about the effect of state depositor preference law adoption. The set of bank-time varying control variables $X$ include the logarithm of banks' total assets (Bank size), and the ratio of equity capital to total assets (Capital ratio. Additionally, the regressions include state-quarter-fixed effects $\left(\gamma_{s t}\right)$ and bank-fixed effects $\left(\gamma_{i}\right) \cdot t$-statistics are reported in parentheses and standard errors are clustered on the bank level. $* * * \mathrm{p}<0.01, * * \mathrm{p}<0.05,{ }^{*} \mathrm{p}<0.1$ 
Table 7

Bank health and profitability

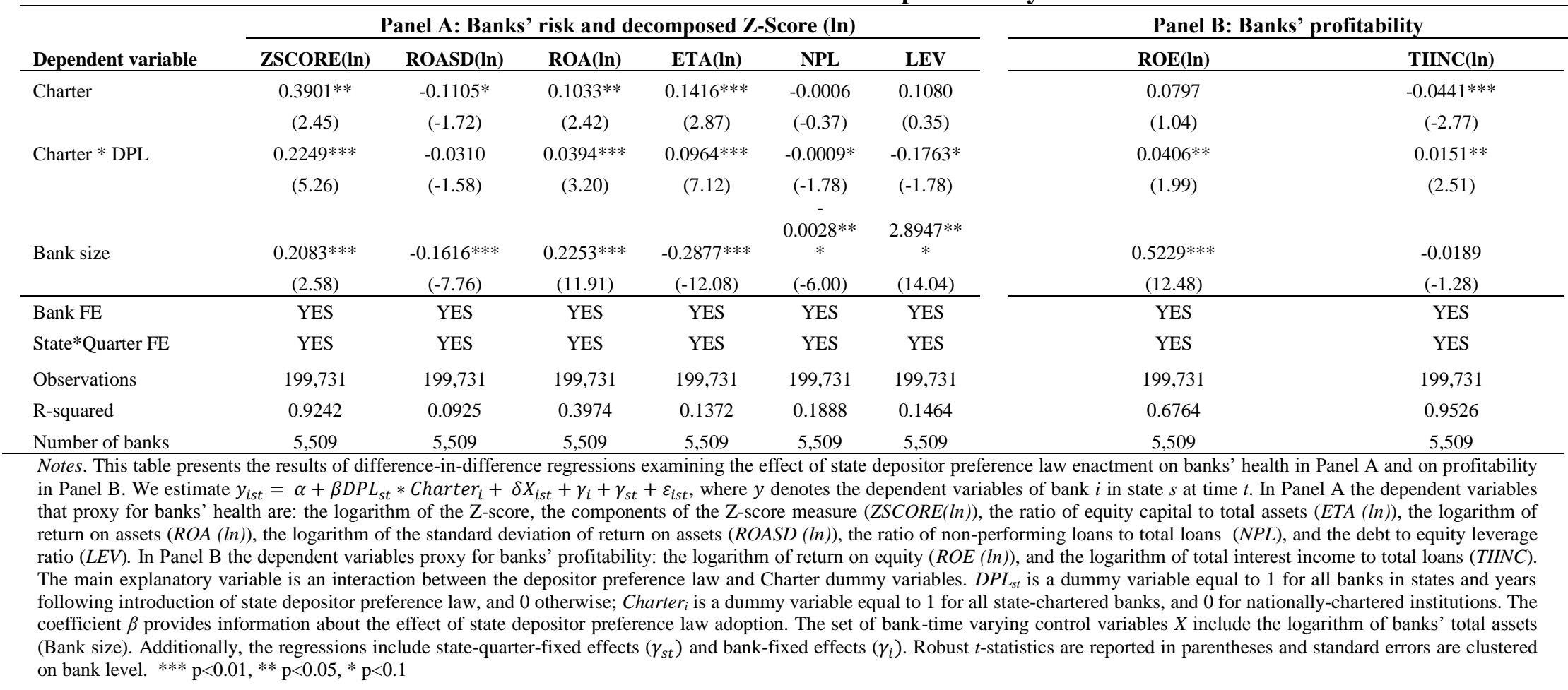


Table 8

Interactions with bank size and switching of bank charters Panel A: Interactions with bank size

\begin{tabular}{|c|c|c|c|c|}
\hline \multicolumn{5}{|c|}{ Panel A: Interactions with bank size } \\
\hline & & Total interest expenses & Interest on deposits & Interest on non-deposits \\
\hline Charter & & $\begin{array}{c}0.2150 \\
(1.40)\end{array}$ & $\begin{array}{c}0.1191 \\
(0.78)\end{array}$ & $\begin{array}{c}-0.0885 \\
(-0.24)\end{array}$ \\
\hline Charter * DPL & & $\begin{array}{c}-0.0192 * * * * \\
(-3.08)\end{array}$ & $\begin{array}{c}-0.0250 * * * \\
(-3.88)\end{array}$ & $\begin{array}{c}0.1298^{* * * *} \\
\quad(5.59)\end{array}$ \\
\hline Bank size & & $\begin{array}{c}0.1663^{* * * *} \\
(11.72)\end{array}$ & $\begin{array}{c}0.1713^{* * *} \\
(12.05)\end{array}$ & $\begin{array}{c}0.1013 * * * \\
(2.94)\end{array}$ \\
\hline Capital ratio & & $\begin{array}{c}-0.0326^{* * * *} \\
(-10.66)\end{array}$ & $\begin{array}{c}-0.0354 * * * \\
(-10.08)\end{array}$ & $\begin{array}{c}0.0272 * * \\
(2.52)\end{array}$ \\
\hline Bank size * DPL & & $\begin{array}{c}-0.0163 * * * \\
(-6.28)\end{array}$ & $\begin{array}{c}-0.0164 * * * \\
(-5.95)\end{array}$ & $\begin{array}{c}-0.0239 * * * \\
(-2.84)\end{array}$ \\
\hline Bank size * Charter & & $\begin{array}{c}-0.0184 \\
(-1.27) \\
\end{array}$ & $\begin{array}{c}-0.0093 \\
(-0.64) \\
\end{array}$ & $\begin{array}{c}0.0006 \\
(0.02) \\
\end{array}$ \\
\hline Bank FE & & YES & YES & YES \\
\hline State*Quarter FE & & YES & YES & YES \\
\hline Observations & & 199,731 & 199,731 & 199,731 \\
\hline R-squared & & 0.6802 & 0.6860 & 0.0272 \\
\hline Number of banks & & 5,509 & 5,509 & 5,509 \\
\hline \multicolumn{5}{|c|}{ Panel C: Removing banks which switch their charter } \\
\hline \multicolumn{2}{|l|}{ Dependent variable } & Total interest expenses & Interest on deposits & Interest on non-deposits \\
\hline DPL & $\begin{array}{c}-0.0003 \\
(-1.01)\end{array}$ & & & \\
\hline Charter * DPL & & $\begin{array}{c}-0.0121^{* * *} \\
(-2.66)\end{array}$ & $\begin{array}{c}-0.0134 * * * \\
(-2.91)\end{array}$ & $\begin{array}{c}0.1099 * * * \\
(4.77)\end{array}$ \\
\hline Bank size & $\begin{array}{c}0.0004 \\
(0.88)\end{array}$ & $\begin{array}{c}0.1816^{* * *} \\
(13.00)\end{array}$ & $\begin{array}{c}0.1942 \text { **** } \\
(14.02)\end{array}$ & $\begin{array}{c}0.0942^{* * * *} \\
(3.34)\end{array}$ \\
\hline Equity & $\begin{array}{l}0.0002 \\
(1.00) \\
\end{array}$ & $\begin{array}{c}-0.0362^{* * * *} \\
(-11.10) \\
\end{array}$ & $\begin{array}{c}-0.0393 * * * \\
(-10.56)\end{array}$ & $\begin{array}{c}0.0346^{* * * *} \\
(3.12)\end{array}$ \\
\hline Bank FE & YES & YES & YES & YES \\
\hline State*Quarter FE & NO & YES & YES & YES \\
\hline State FE & NO & & & \\
\hline Quarter FE & YES & & & \\
\hline Observations & 147,367 & 170,873 & 170,873 & 170,873 \\
\hline R-squared & 0.0360 & 0.5642 & 0.5756 & 0.0218 \\
\hline Number of banks & 5,509 & 5,454 & 5,454 & 5,454 \\
\hline \multicolumn{5}{|c|}{$\begin{array}{l}\text { Notes: Panel A appends equation (2) with interactions between bank size and the } D P L_{s t} \text { and the } C h a r t e r_{i} \text { dummy variables. Panel B presents results for probit regressions where our dependent variable is a dummy } \\
\text { variable equal to } 1 \text { when bank switches charter and } 0 \text { otherwise. Panel C shows regressions identical to those reported in Table } 5 \text { except for the fact that we omit banks which switch their charter. We estimate } y_{i s t}= \\
\alpha+\beta D P L_{s t} * C h a r t e r_{i}+\delta X_{i s t}+\gamma_{i}+\gamma_{s t}+\varepsilon_{i s t} \text {, where } y \text { denotes the dependent variable of bank } i \text { in state } s \text { at time } t \text {, which include ratios of: total interest expenses to total liabilities (Total interest expenses), } \\
\text { interest on deposits to total deposits (Interest on deposits), and interest on other non-deposits to total other non-deposits (Interest on non-deposits). The main explanatory variable is an interaction between the depositor } \\
\text { preference law and Charter dummy variables. } D P L_{s t} \text { is a dummy variable equal to } 1 \text { for all banks in states and years following introduction of state depositor preference law, and } 0 \text { otherwise; Charter } r_{i} \text { is a dummy } \\
\text { variable equal to } 1 \text { for all state-chartered banks, and } 0 \text { for nationally-chartered institutions. The set of bank-time varying control variables } X \text { includes the logarithm of banks' total assets (Bank size), and the ratio of } \\
\text { equity capital to total assets (Capital ratio). Additionally, the regressions in Panels A and C include state-quarter-fixed effects }\left(\gamma_{s t} \text { ) and bank-fixed effects }\left(\gamma_{i}\right) \text {. Robust } t \text {-statistics are reported in parentheses and }\right. \\
\text { standard errors are clustered on bank level. *** p p }<0.01, * * \mathrm{p}<0.05, * \text { p }<0.1 \text {. }\end{array}$} \\
\hline
\end{tabular}


Table 9

Confounding events: Banking crises in New England, Texas, and turmoil in the S\&L industry

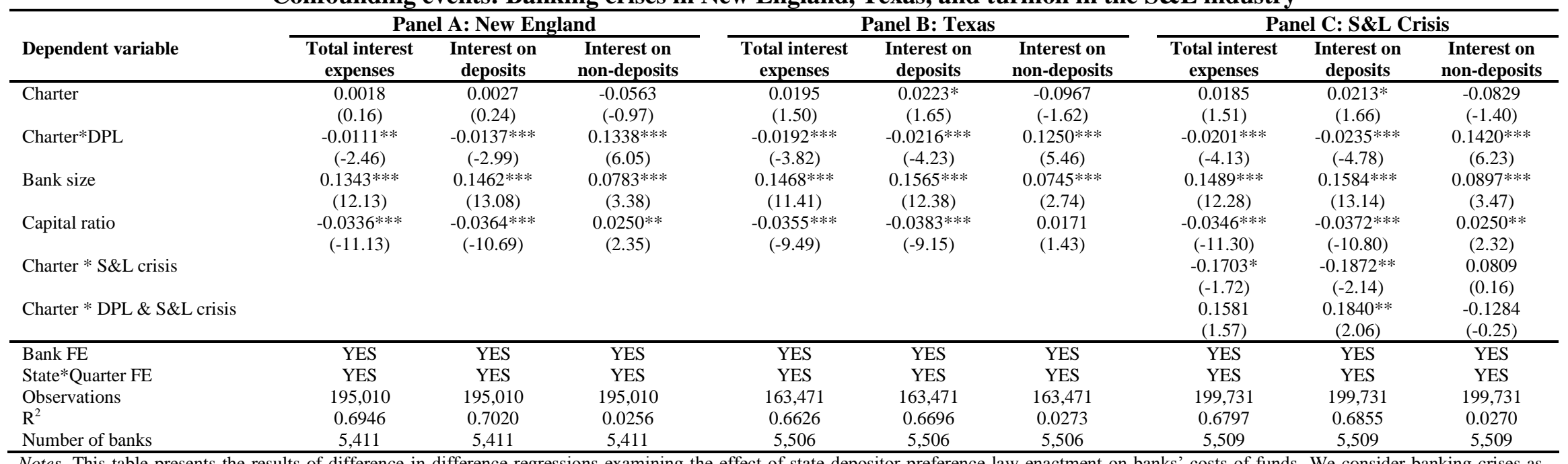

Notes. This table presents the results of difference-in-difference regressions examining the effect of state depositor preference law enactment on banks' costs of funds. We consider banking crises as confounding events and remove Connecticut, Maine, New Hampshire, and Rhode Island in Panel A from the sample. We remove observations for Texas from the sample in Panel B. Panel C focuses on the S\&L crisis by including additional interaction terms between the dummy for state charters and our proxy for the S\&L crisis, and a triple interaction term between the dummy for state-chartered banks, the dummy variable for depositor preference, and the proxy for the S\&L crisis. We estimate $y_{i s t}=\alpha+\beta D P L_{s t} *$ Charter $_{i}+\delta X_{i s t}+\gamma_{i}+\gamma_{s t}+\varepsilon_{i s t}$, where $y$ denotes the dependent variable of bank $i$ in state $s$ at time $t$, which include ratios of: total interest expenses to total liabilities (Total interest expenses), interest on deposits to total deposits (Interest on deposits), and interest on other non-deposits to total other non-deposits (Interest on non-deposits). The main explanatory variable is an interaction between the depositor preference law dummy and Charter dummy variable. $D P L_{s t}$ is a dummy variable equal to 1 for all banks in states and years following introduction of state depositor preference law, and 0 otherwise; Charter $r_{i}$ is a dummy variable equal to 1 for all state-chartered banks, and 0 for nationally-chartered institutions. The coefficient $\beta$ provides information about the effect of state depositor preference law adoption. The set of bank-time varying control variables $X$ include the logarithm of banks' total assets (Bank size), the ratio of equity capital to total assets (Capital ratio), inter- and intra-state deregulation dummy variables, and an S\&L crisis proxy (measured as the ratio of failed thrift assets to total bank assets in the state). Additionally, the regressions include state-quarter-fixed effects $\left(\gamma_{s t}\right)$ and bank-fixed effects $\left(\gamma_{i}\right)$. $t$-statistics are reported in parentheses and standard errors are clustered on the bank level. *** $\mathrm{p}<0.01, * * \mathrm{p}<0.05, * \mathrm{p}<0.1$. 
Table 10

Confounding events: Regulation and deregulation of banking markets

Dependent variable

Panel A: Excluding FIRREA period

\begin{tabular}{ccc}
$\begin{array}{c}\text { Total } \\
\text { interest }\end{array}$ & $\begin{array}{c}\text { Interest on } \\
\text { deposits }\end{array}$ & $\begin{array}{c}\text { Interest on } \\
\text { non- }\end{array}$ \\
\hline
\end{tabular}

Charter

expen

Charter*DPL

expenses

deposits

non-

Charter*DP

$(1.28)$
$-0.0313 * * *$

0.0327

-

Panel B: Excluding FDICIA period

\section{Bank size}

$(-4.69)$

$(1.30)$

$-0.0057$

Total Interest on

\begin{tabular}{ccc}
$\begin{array}{c}\text { interest } \\
\text { expenses }\end{array}$ & $\begin{array}{c}\text { Interest on } \\
\text { deposits }\end{array}$ & $\begin{array}{c}\text { non- } \\
\text { deposits }\end{array}$ \\
\hline
\end{tabular}

\section{Capital ratio}

$0.3264 * * *$

$(-0337 * * *$

$(-0.06)$

(14.75)

$(-4.83)$
$0.3469 * * *$

(5.16)

0.0065

0.0092

deposits

$(0.47) \quad(0.65)-(-1.21)$

$-0.0116^{* * *}$

$(0.65)$
$-0.0132 * * *$

$(-1.21)$

$(-2.51)$

-0.0132
$(-2.81)$

$0.1161 * * *$

$(15.52)-0.1158^{*}$

$0.1821 * * *$
$(13.26)$

$0.1948 * * *$

$(4.98)$
$0.0909 * * *$

$-0.0999 * * * \quad 0.0135$

$(13.26)$
$-0.0366 * * *$

(14.30)

$0.0909^{* * * *}$
$(3.23)$

$(-11.25)$

$-0.0397 * *$

$0.0348 * * *$

(-16.21)

(0.98)

(-10.70)

(3.14)

\begin{tabular}{ccc}
\multicolumn{2}{c}{ Panel C: Deregulation of banking markets } \\
\hline $\begin{array}{c}\text { Total } \\
\text { interest } \\
\text { expenses }\end{array}$ & $\begin{array}{c}\text { Interest } \\
\text { on } \\
\text { deposits }\end{array}$ & $\begin{array}{c}\text { Interest on } \\
\text { non-deposits }\end{array}$ \\
\hline 0.0185 & 0.0210 & -0.0968 \\
$(1.47)$ & $(1.60)$ & $(-1.61)$ \\
$-0.0161 * * *$ & $-0.0199 * * *$ & $0.1174 * * *$ \\
$(-3.44)$ & $(-4.17)$ & $(4.23)$ \\
$0.1488^{* * * *}$ & $0.1584^{* * *}$ & $0.0910^{* * * *}$ \\
$(12.29)$ & $(13.14)$ & $(3.51)$ \\
$-0.0345 * * *$ & $-0.0372^{* * *}$ & $0.0240^{* *}$ \\
$(-11.26)$ & $(-10.76)$ & $(2.23)$ \\
-0.0075 & -0.0047 & 0.0288 \\
$(-0.80)$ & $(-0.49)$ & $(0.79)$ \\
0.0059 & 0.0056 & 0.0247 \\
$(0.65)$ & $(0.60)$ & $(0.61)$ \\
-0.0028 & -0.0056 & 0.0614 \\
$(-0.18)$ & $(-0.41)$ & $(1.23)$ \\
-0.0032 & -0.0020 & -0.0703 \\
$(-0.21)$ & $(-0.15)$ & $(-1.39)$ \\
YES & YES & YES \\
YES & YES & YES \\
199,731 & 199,731 & 199,731 \\
0.6797 & 0.6855 & 0.0271 \\
5,509 & 5,509 & 5,509 \\
\hline
\end{tabular}

Charter * Interstate * DPL

Charter * Intrastate

Charter * Intrastate * DPL

\begin{tabular}{|c|c|c|c|c|c|c|c|c|c|}
\hline Bank FE & YES & YES & YES & YES & YES & YES & YES & YES & YES \\
\hline State*Quarter FE & YES & YES & YES & YES & YES & YES & YES & YES & YES \\
\hline Observations & 137,401 & 137,401 & 137,401 & 172,696 & 172,696 & 172,696 & 199,731 & 199,731 & 199,731 \\
\hline $\mathrm{R}^{2}$ & 0.8923 & 0.8925 & 0.1619 & 0.5609 & 0.5723 & 0.0215 & 0.6797 & 0.6855 & 0.0271 \\
\hline Number of banks & 5,471 & 5,471 & 5,471 & 5,508 & 5,508 & 5,508 & 5,509 & 5,509 & 5,509 \\
\hline
\end{tabular}

Notes. This table presents the results of difference-in-difference regressions examining the effect of state depositor preference law enactment on banks' costs of funds. To rule out the role of changes in regulation, we remove in Panel A observations between 1989Q4 and 1993Q2 to consider the effect of FIRREA. Panel B removes observations between 1991Q4 and 1993Q2 to consider the effect of FDICIA. Panel C presents the results of difference-in-difference-in-difference regressions examining the robustness of the results to including interstate and intrastate deregulation interactions. For Panel A and $\mathrm{B}$, we estimate $y_{i s t}=$ interest on deposits to total deposits (Interest on deposits), and interest on other non-deposits to total other non-deposits (Interest on non-deposits). The main explanatory variable is an interaction between the depositor preforte

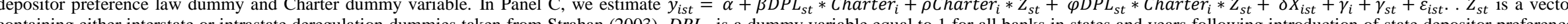
containing either law, and o ot state deposito dummy variables, and an S\&L crisis proxy (measured as the ratio of failed thrift assets to total bank assets in the state). Additionally, the regressions include state-quarter-fixed effects $\left(\gamma_{s t}\right)$ and bank-fixed effects $\left(\gamma_{i}\right) . t$-statistics are reported in parentheses and standard errors are clustered on the bank level. *** $\mathrm{p}<0.01, * * \mathrm{p}<0.05, * \mathrm{p}<0.1$ 
Table 11

Further sensitivity tests

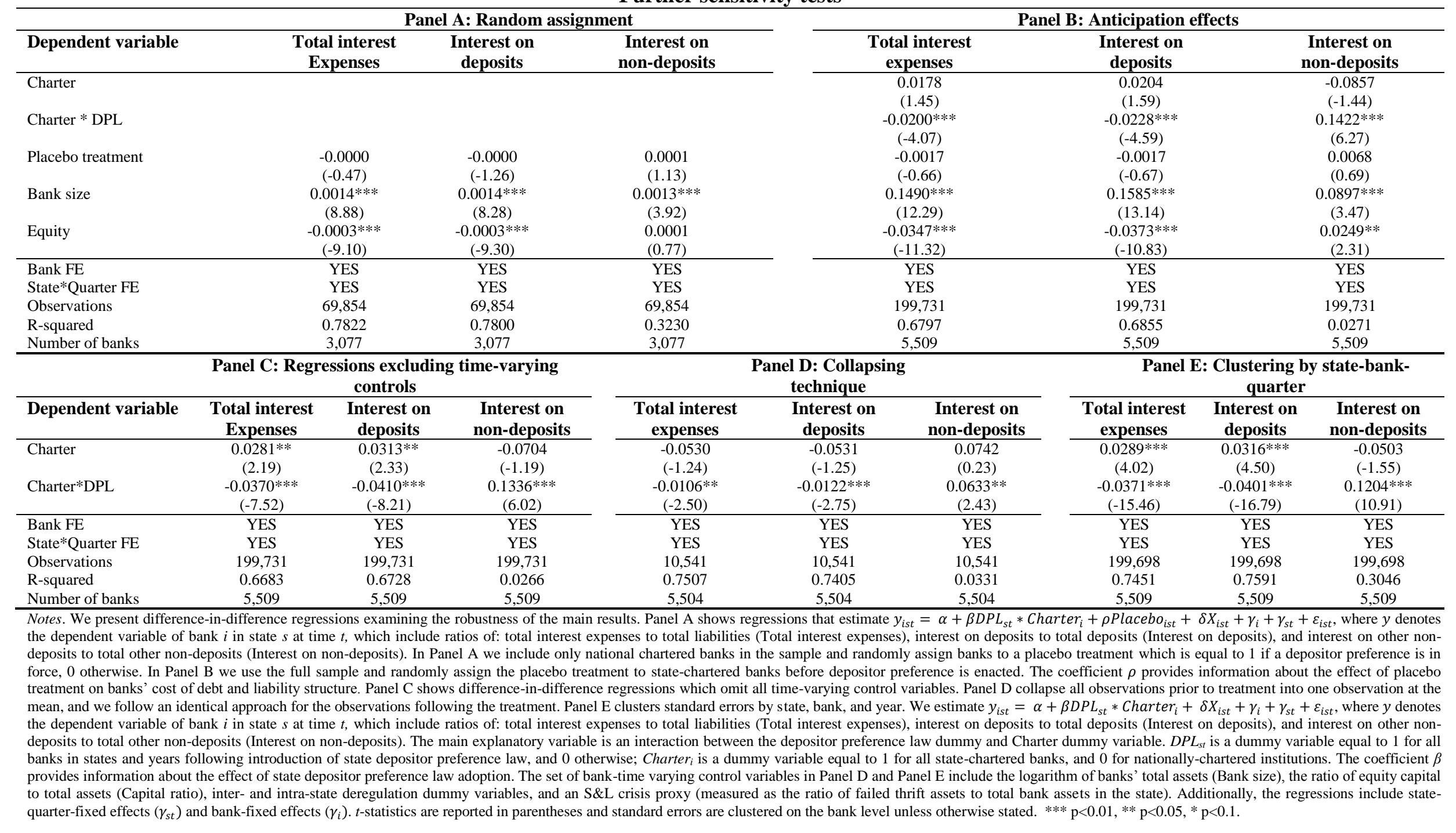


Table 12

Falsification exercise and external validity: The effect of national depositor preference (Sample 1983Q1-1997Q3)

Panel A: Monte Carlo simulations for the effect of national depositor preference

\begin{tabular}{|c|c|c|c|}
\hline Total interest expenses & Interest on deposits & \multicolumn{2}{|c|}{ Interest on non-deposits } \\
\hline Number of replications: & Number of replications: & \multicolumn{2}{|c|}{ Number of replications: } \\
\hline 1,000 & 1,000 & \multicolumn{2}{|c|}{1,000} \\
\hline Rejection rate at the $1 \%$ level & Rejection rate at the $1 \%$ level & \multirow{2}{*}{\multicolumn{2}{|c|}{$\begin{array}{l}\text { Rejection rate at the } 1 \% \text { level } \\
\text { (2-tailed test): }\end{array}$}} \\
\hline (2-tailed test): & (2-tailed test): & & \\
\hline $0.7 \%$ & $1.1 \%$ & \multicolumn{2}{|c|}{$1.2 \%$} \\
\hline Rejection rate at the $5 \%$ level & Rejection rate at the $5 \%$ level & \multirow{2}{*}{\multicolumn{2}{|c|}{$\begin{array}{l}\text { Rejection rate at the } 5 \% \text { level } \\
\text { (2-tailed test): }\end{array}$}} \\
\hline$(2$-tailed test $):$ & (2-tailed test): & & \\
\hline $4.0 \%$ & $5.7 \%$ & \multicolumn{2}{|c|}{$4.9 \%$} \\
\hline Rejection rate at the $10 \%$ level & Rejection rate at the $10 \%$ level & \\
\hline (2-tailed test): & (2-tailed test): & \multirow{2}{*}{\multicolumn{2}{|c|}{$\begin{array}{c}\text { (2-tailed test): } \\
9.5 \%\end{array}$}} \\
\hline $7.8 \%$ & $11.0 \%$ & & \\
\hline \multicolumn{4}{|c|}{ Panel B: The effect of national depositor preference } \\
\hline Dependent variable & Total interest expenses & Interest on deposits & Interest on non-deposits \\
\hline Treatment group & $\begin{array}{c}0.0042 \\
(0.62)\end{array}$ & $\begin{array}{l}0.0065 \\
(0.89)\end{array}$ & $\begin{array}{r}-0.0418 \\
(-0.70)\end{array}$ \\
\hline \multirow[t]{2}{*}{ National DPL } & $-0.8503 * * *$ & $-0.8556^{* * *}$ & $-0.1747 * * *$ \\
\hline & $(-155.13)$ & $(-148.97)$ & $(-6.24)$ \\
\hline \multirow[t]{2}{*}{ Treatment group * national DPL } & $-0.0160 * * *$ & $-0.0327 * * *$ & $0.1754 * * *$ \\
\hline & $(-5.86)$ & $(-9.84)$ & \\
\hline \multirow[t]{2}{*}{ Bank size } & $0.1107 * * *$ & $0.1068^{* * * *}$ & $0.1381 * * *$ \\
\hline & $(25.18)$ & & (7.87) \\
\hline \multirow{2}{*}{ Capital ratio } & $-0.0439 * * *$ & $-0.0500 * * *$ & $0.0567 * * *$ \\
\hline & $(-17.72)$ & $(-18.24)$ & (5.97) \\
\hline Bank FE & YES & YES & YES \\
\hline Quarter FE & YES & YES & YES \\
\hline Observations & 600,910 & 600,910 & 600,910 \\
\hline $\mathrm{R}^{2}$ & 0.6917 & 0.6813 & 0.1269 \\
\hline Number of banks & 14,656 & 14,656 & 14,656 \\
\hline \multicolumn{4}{|c|}{ 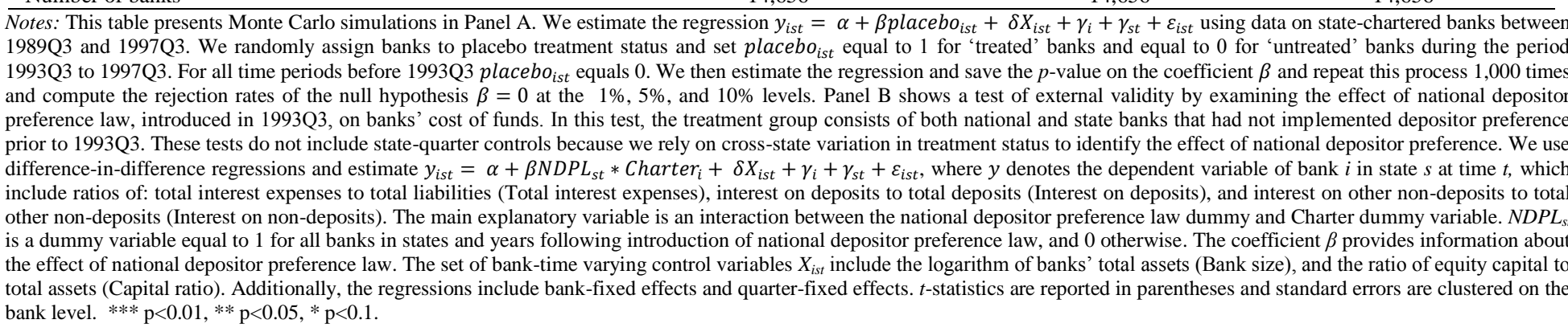 } \\
\hline
\end{tabular}




\section{Figures}

Figure 1

Development of state depositor preference laws in the U.S.

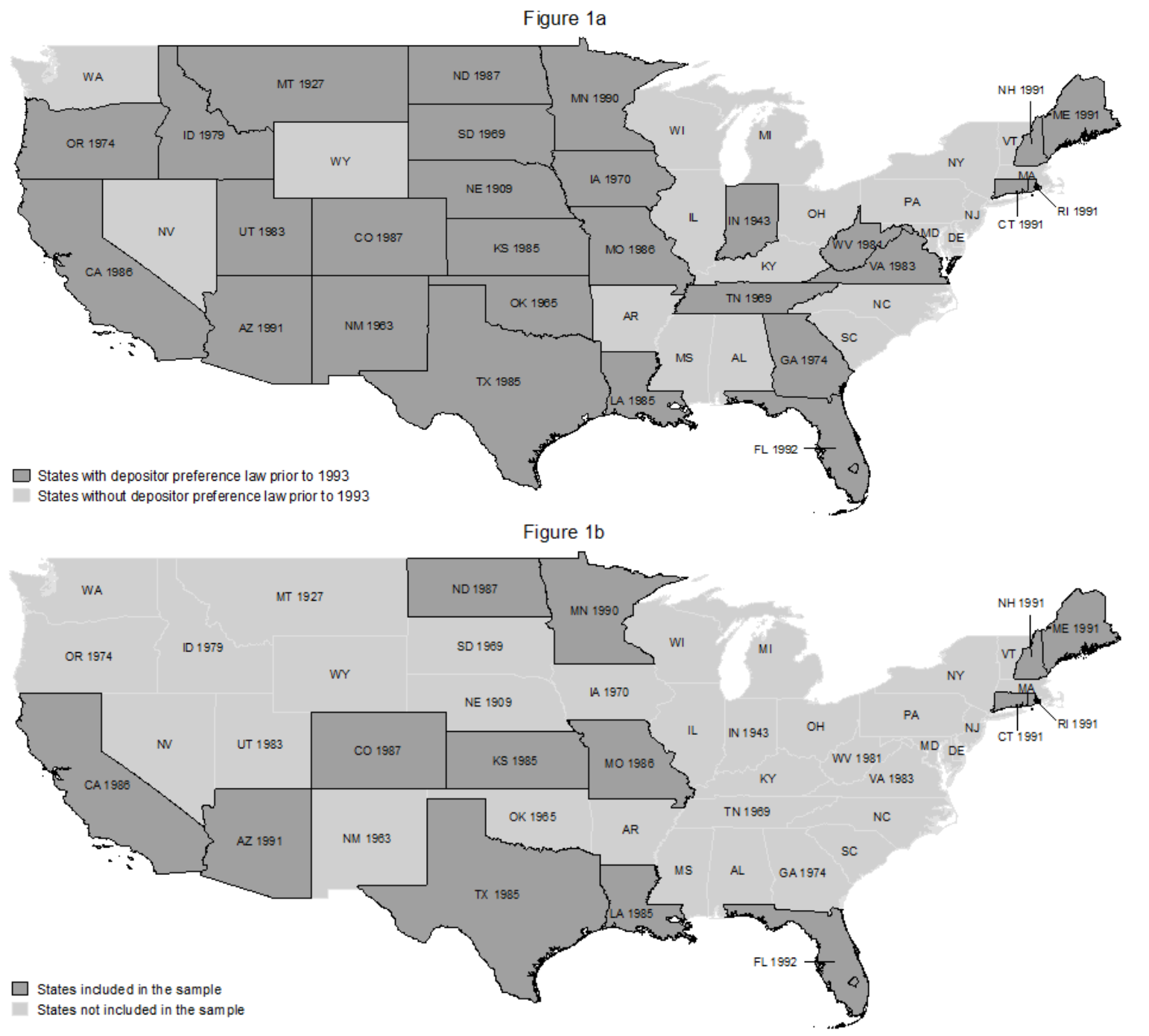


Figure 2

\section{Parallel trends}
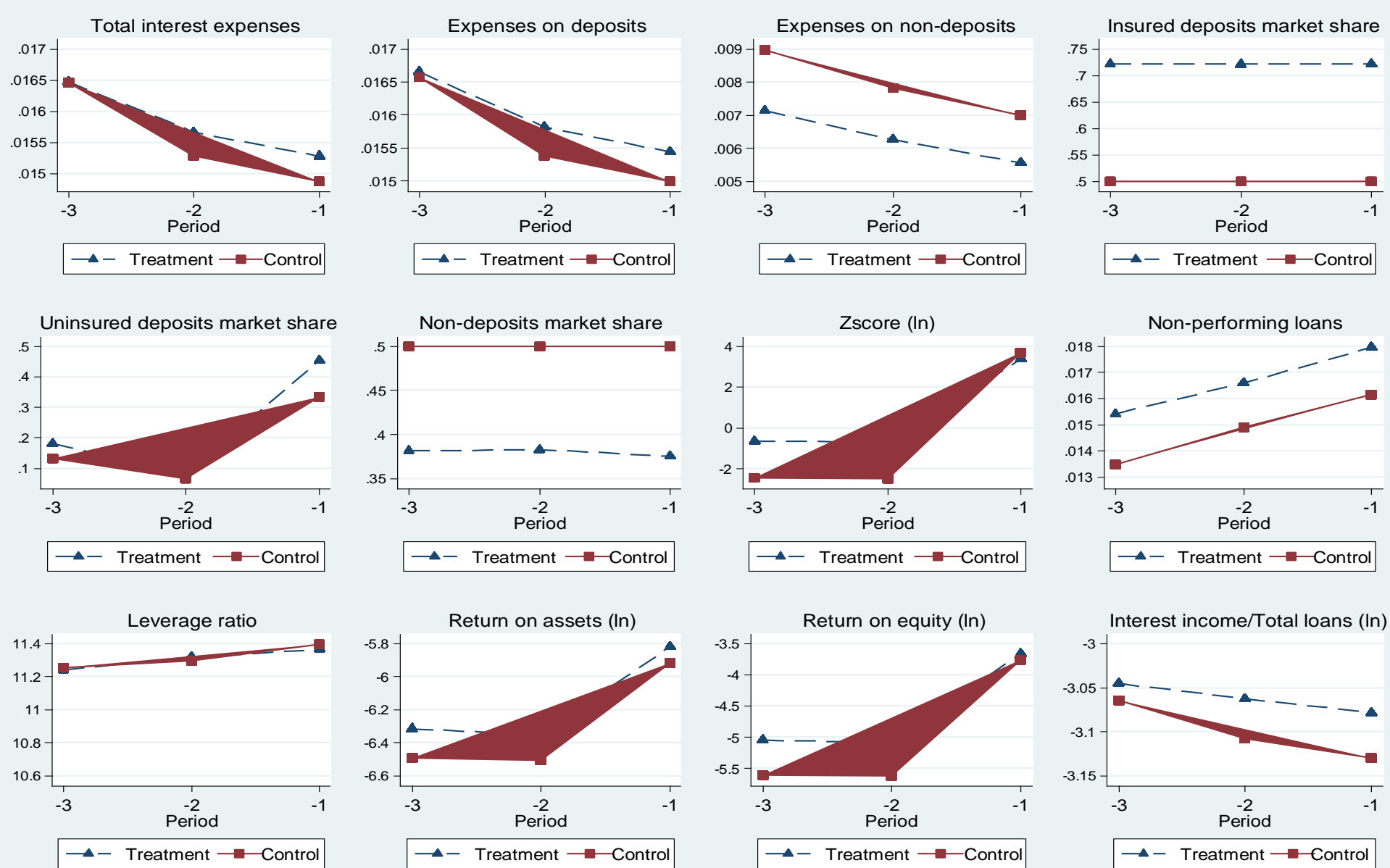

Notes: Figure 2 illustrates the behavior of quarterly changes in the dependent variables, for three quarters preceding depositor preference law enactment. State-chartered banks (the treatment group) are represented by a triangle, whereas national-chartered banks (the control group) are depicted by a square. 


\section{Appendix A: Details on the introduction of depositor preference laws for each state}

\section{$\underline{\text { Arizona }\left(21^{\text {st }} \text { September 1991) }\right.}$}

\section{Party control}

Governor: R $\quad$ Party control upper and lower house: $\mathrm{R}$

\section{Legal provision}

Priority of claims; interest

A. Claims allowed in a proceeding under this article shall be paid in the following order:

1. Costs and expenses of the administration of the receivership and liquidation.

2. Taxes due to this state.

3. Claims with priority under the laws of this state and under federal law.

4. Claims of creditors that are fully secured including contract claims for interest to the date of payment.

5. Claims of depositors.

6. Claims of general creditors.

7. Claims on obligations that are subordinated to the claims of general creditors.

B. Claims that are approved shall bear interest calculated as provided by law or by judgement from the date that the court grants the superintendent's application for the appointment of a receiver for that bank to the extent that monies are available to pay that interest. If monies are not available to pay interest, the interest shall be prorated. Interest owned shall receive the same priority as the claim on which it accrues, but interest on a claim shall not be paid until all claims with that same class have receive payment of the full principal amount of the claim.

C. Any monies remaining after the payment of claims as provided in this section shall be returned to the stockholders of the bank as prescribed by this article.

\section{Further particulars and coinciding factors}

The ongoing bank merger wave affects many counties in Arizona. A merger between BankAmerica and Security Pacific and the NCNB-C\&S Sovran consolidation result in concentrated banking conditions in Arizona as the merger partners operate competing offices there.

\section{California $\left(27^{\text {th }}\right.$ June 1986)}

\section{Party control}

Governor: R Party control upper and lower house: D

\section{Legal provision}

(a) Expenses and claims of unsecured creditors have priority in the following order:

(1) Expenses of liquidation and approved claims for fees and assessments due the department.

(2) Approved claims given priority under other provisions of state or federal law, including, but not limited to, Sections 3114 and 3240 
(3) Approved claims for "deposits", as that term is defined in 12 U.S.C. Section $1813(l)$, but including obligations of the type described in 12 U.S.C. Section 1813(l) (5) (A) and (B).

(4) Approved claims for other general liabilities.

(5) Approved claims for obligations subordinated to deposits and other general liabilities.

(b) Interest shall be given the same priority as the claim on which it is based, but no interest shall be paid on any claim until the principal of all claims within the same class has been paid or adequately provided for in full.

(c) Any funds remaining shall be paid to shareholders.

\section{Further particulars and coinciding factors}

The authorities also emphasize that these provisions facilitate the structuring of purchase and assumption transactions and enable depositors to have quick access to their funds.

The savings and loans crisis gets much attention in the press after Seapointe Savings and Loan Association collapses, and the bank merger wave also affects many counties in California. Energy prices are reported to decline.

\section{Colorado (1 ${ }^{\text {st }}$ May 1987)}

\section{Party control}

Governor: D $\quad$ Party control upper and lower house: R

\section{Legal provision}

Liquidation by commissioner - procedure. (9) (a) On liquidation of a state bank, after payment of federal deposit insurance, claims for payment have the following priority:

(I) Obligations incurred by the commission, fees and assessment due to the division, and expenses of liquidation, all of which may be covered by a proper reserve of funds;

(II) Claims of depositors having an approved claim against the general liquidation account of the bank;

(III) Claims of general creditors having an approved claim against the general liquidating account of the bank;

(IV) Claims otherwise proper that were not filed within the time prescribed by this code;

(V) Approved claims of subordinate creditors; and

(VI) Claims of stockholders of the bank.

\section{Further particulars and coinciding factors}

Big bank holding companies and the thrift industry report weak performance.

\section{Connecticut $\left(22^{\text {nd }}\right.$ May 1991)}

\section{Party control}

Governor: Independent Party control upper and lower house: D

\section{Legal provision}


Section 1. Section 36-51 of the general statutes is repealed and the following is substituted in lieu thereof:

(a) The avails of the property of any capital stock bank organized under the laws of this state in the hands of a receiver shall be distributed in the following order of priority:

(1) The charges and expenses of settling its affairs;

(2) the circulating notes, if any;

(3) all deposits;

(4) all sums which have been subscribed and paid in for its stock by the state or the school fund;

(5) all other liabilities; and

(6) the claims of stockholders.

\section{Further particulars and coinciding factors}

Connecticut was affected by the New England banking crisis. Several news items focus on the problems surrounding Bank of New England. The media criticize regulators for lax supervision. Other news items highlight poor performance of the banking industry, reflected in rising loan loss reserves, dividend cuts, and banks raise capital under regulatory pressure.

\section{Florida (3 ${ }^{\text {rd }}$ July 1992)}

\section{Party control}

Governor: D $\quad$ Party control upper and lower house: Split between R and D

\section{Legal provision}

Transfers by banks and other acts in contemplation of insolvency.

(1) Any and all transfers of the notes, bonds, bills of exchange, or other evidences of debt owing to any bank or trust company or of deposits to its credit; all assignments of mortgages, securities, or real estate or of any judgments or decrees in its favor; all deposits of money, bullion, or other valuable thing for its use or for the use of any of its stockholders or creditors; and all payments of money to either, made after the commission of an act of insolvency or in contemplation thereof made with a view to the preference of one creditor to another shall be void.

(2) Unsecured claims for payment against any financial institution shall have the following priority for any distribution made after July 3, 1992:

(a) Expenses of the liquidation or the receivership estate;

(b) State claims;

(c) Approved claims for a "deposit," as that term is defined in 12 U.S.C. s. 1813(l);

(d) Approved claims for other general creditors;

(e) Approved claims for obligations subordinate to deposits and other general liabilities; and

(f) Shareholders' claims in proportion to the stock held by them respectively or their interest therein as appearing.

(3) Except in any action brought by the department, no attachment, injunction, or execution shall be enforced against such financial institution or any of its property before final judgment in any suit, action, or proceeding in any state or federal court.

\section{Further particulars and coinciding factors}

Several media sources report on improved bank performance in terms of higher earnings and lower loan losses at banks with operations in Florida. 


\section{$\underline{\text { Hawaii }\left(24^{\text {th }} \text { June 1987) }\right.}$}

\section{Party control}

Governor: D $\quad$ Party control upper and lower house: D

\section{Legal provision}

Priority of expenses and claims. In the event of the insolvency or voluntary or involuntary liquidation of any bank under this chapter, the expenses and claims shall have priority in the following order:

(1) Administrative expenses;

(2) Unsecured claims for wages, salaries, or commissions, including vacation, severance or sick leave pay, earned by an individual within ninety days before the date of the commissioner's position in and amount not exceeding \$,2000 for each individual.

(3) Claims of depositors. Any corporation guaranteeing or insuring the deposits is subrogated to all rights of the owners of such deposits to the extent of payment. The right of any agency of the Unites States insuring depositors to be subrogated to the rights of depositors upon payment of their claims may not be less extensive than the law of the United States requires as a condition of the authority to issue such insurance or make such payments to depositors of national banks;

(4) All other unsecured claims in amounts allowed by the court, including claims of secured creditors to the extent the amount of their claims exceed the present fair market value of their collateral, the claim of a lessor for damages resulting from the termination of a lease of property may not be allowed in an amount in excess of the rent reserved by the lease, without acceleration for sixty days after the lessor repossessed the leased property, or the leased property was surrendered to the lessor, whichever first occurs, whether before or after the commissioner took possession of the institution, plus any unpaid rent due under the lease, without acceleration, on the date of possession or surrender. A claim for damages resulting from the termination of an employment contract, may not be allowed an amount in excess of the compensation provided by the contract, without acceleration, for ninety days after the employee was directed to terminate or the employee terminated performance under the contract whichever first occurs, whether before or after the commissioner took possession of the institution, plus any unpaid compensation due under the contract, without acceleration, on the data the employee was directed to terminate to the employee terminated performance. Claims for damages resulting from the termination of employment contract of persons who were in control of the institution are not entitled to priority under this subsection;

(5) Claims for debts that tare subordinated under the provisions of a subordination agreement or other instrument;

(6) Claims of depositors who are controlling persons;

(7) Claims of persons who were at any time in control of the intuition;

(8) All other claims.

\section{Further particulars and coinciding factors}

News items focus on the islands' dominant bank, Bancorp Hawaii, which is prospering and deemed to be headed for another year of excellent performance. 


\section{$\underline{\text { Kansas }\left(1^{\text {st }} \text { July 1985) }\right.}$}

\section{Party control}

Governor: D $\quad$ Party control upper and lower house: R

\section{Legal provision}

Receiver to take charge of assets; order of payment.

(a) A receiver appointed pursuant to K.S.A. 9-1905 and amendments thereto, under the direction of the commissioner, shall take charge of any insolvent or critically undercapitalized bank or trust company and all of its assets and property, and liquidate the affairs and business thereof for the benefit of its depositors, creditors and stockholders. The receiver may sell or compound all bad and doubtful debts and sell all the property of the bank or trust company upon such terms as the district court of the county where the bank or trust company is located shall approve. The receiver shall pay over all moneys received to the creditors and depositors of such bank or trust company as ordered by the commissioner

(b) In distributing assets of the insolvent or critically undercapitalized bank or trust company in payment of its liabilities, the order of payment, in the event its assets are insufficient to pay in full all of its liabilities, shall be by category as follows:

(1) The costs and expenses of the receivership and real and personal property taxes assessed against the bank pursuant to applicable law;

(2) claims which are secured or given priority by applicable law;

(3) claims of unsecured depositors;

(4) all other claims exclusive of claims on capital notes and debentures;

(5) claims on capital notes and debentures.

Should the assets be insufficient for the payment in full of all claims within a category, such claims shall be paid in the order provided by other applicable law or, in the absence of such applicable law, pro rata

\section{Further particulars and coinciding factors}

There are no notable news items in the media about banks in Kansas.

\section{$\underline{\text { Louisiana }\left(\mathbf{1}^{\text {st }} \text { January } 1985\right)}$}

\section{Party control}

Governor: D $\quad$ Party control upper and lower house: D

\section{Legal provision}

Distribution of assets

A. All claims against the bank's assets, proved to the receiver's satisfaction or approved by the receivership court shall be paid in the following order:

(1)Administration expenses of the liquidation.

(2)Claims given priority under other provisions of state or federal law.

(3)Deposit obligations.

(4)Other general liabilities.

(5)Debt subordinated to the claims of depositors and general creditors.

(6)Equity capital securities.

\section{Further particulars and coinciding factors}


There are no notable news items in the media about banks in Louisiana.

\section{Maine $\left(16^{\text {th }}\right.$ April 1991)}

\section{Party control}

Governor: R $\quad$ Party control upper and lower house: D

\section{Legal provision}

Procedures in liquidation.

When the superintendent appoints the Federal Deposit Insurance Corporation as receiver, federal law prescribes the procedures that the Federal Deposit Insurance Corporation follows in liquidation of the insolvent bank. When an insolvent stock institution or an insolvent mutual institution is liquidated, assets must be distributed in the following priority:

A. First, the payment of the costs and expenses of the liquidation:

B. Second, the payment of claims for deposits, including, but not limited to, the claims of depositors in a mutual institution for the return of their deposits;

C. Third, the payment of all debts, claims and obligations owed by the institution and not accorded priority pursuant to paragraphs $A$ and $B$;

D. Fourth, the payment of claims otherwise proper that were not filed with the prescribed time; and

E. Fifth, the payment of any obligation expressly subordinated to deposits and to claims entitled to the priority established by paragraphs $A$ and $B$.

\section{Further particulars and coinciding factors}

There is an emergency preamble which highlights that supervisory powers are to be enhanced to deal with presently volatile economic conditions which warrant prompt responsive action by the Superintendent of Banking. Acquisitions may also be facilitated by determination of the Superintendent of Banking if he deems this is important to protect depositors.

Maine was affected by the New England banking crisis. Several press items focus on the Bank of New England and problems in the real estate market.

\section{$\underline{\text { Minnesota }\left(24^{\text {th }} \text { April 1990) }\right.}$}

\section{Party control}

Governor: R $\quad$ Party control upper and lower house: D

\section{Legal provision}

Subd. 9. [DIVIDENDS ON CLAIMS.] At any time after the expiration of the date fixed for the presentation of claims the commissioner may, out of the funds remaining on hand after the payment of expenses and amounts due to depositors, declare one or more dividends, and after the expiration of one year from the first publication of notice to creditors, may declare a final dividend, such dividends to be paid to such persons in such amounts as may be directed by the district court.

\section{Further particulars and coinciding factors}


A small number of news items indicate improved performance of Minnesota based banks.

\section{$\underline{\text { Missouri }\left(15^{\text {th }} \text { May 1986) }\right.}$}

\section{Party control}

Governor: R $\quad$ Party control upper and lower house: D

\section{Legal provision}

Claims entitled to priority, liquidation or insolvency. - In case of the insolvency or voluntary or involuntary liquidation of any corporation to which this chapter is applicable, the following claims shall have priority in the order herein specified:

(1) All unpaid charges lawfully assessed against it by the director and all unpaid penalties and forfeitures incurred by it under any section of this chapter, and all expenses of liquidation;

(2) The depositors having an approved claim against the general liquidating account of the bank;

(3) The general creditors having an approved claim against the liquidating account of the bank;

(4) The claims otherwise proper which were not filed within ghe time presecribed in this chapter;

(5) The stockholders of the bank.

\section{Further particulars and coinciding factors}

There are no notable news items in the media about banks in Missouri.

\section{$\underline{\text { New Hampshire }\left(10^{\text {th }} \text { June } 1991\right)}$}

\section{Party control}

Governor: R $\quad$ Party control upper and lower house: $\mathrm{R}$

\section{Legal provision}

Distribution of Assets. Payments of dividends under RSA 395:19 and any other proceeds of the property of a closed or insolvent New Hampshire depository institution shall be distributed according to the decree of the court in the following priority:

I. The payment of the costs and expenses of the liquidation.

II. The payment of wage, salary and other claims of employees to the same extent such claims would be accorded priority under federal bankruptcy law.

III. The payment of claims for deposit accounts including but not limited to "deposits" as defined in 12 U.S.C. section 1813(l), or as it may be later amended from time to time.

IV. The payment of liens accorded priority under New Hampshire law.

$V$. The payment of all debts, claims, and obligations filed in accordance with RSA 395:13, not accorded priority in the preceding paragraphs.

VI. The payment of delayed claims in accordance with RSA 395:16.

VII. The payment of capital debentures issued under RSA 384:14- $a$ and any other obligations expressly subordinated to deposits and to claims entitled to the priority established in the preceding paragraphs.

VIII. Any funds remaining shall be divided in the case of a stock institution among the stockholders according to their respective interests or, in the case of a mutual 
institution, among the depositors in proportion to the respective amounts of their deposits.

IX. Interest shall be given the same priority as the claim on which it is based, but no interest shall be paid on any claim until the principal of all claims within the same class and all higher-priority classes have been paid or adequately provided for in full.

\section{Further particulars and coinciding factors}

New Hampshire was affected by the New England banking crisis. Newspapers report on declining bank earnings, and woes about banking problems are increasing. Several news items link the banking problems to collapsing real estate markets.

\section{North Dakota (1 ${ }^{\text {st }}$ July 1987)}

\section{Party control}

Governor: D $\quad$ Party control upper and lower house: Split between R and D

\section{Legal provision}

Priority of expenses and claims.

The order of paying the expenses of and claims against an insolvent bank is:

1. Administrative expenses, including salaries and expenses of receivers pursuant to section 6-07-20, and expenses incurred by the commissioner during possession or in the course of proceedings under this chapter including the compensation of deputy examiners, agents, and clerks employed by the commissioner and reasonable fees for BANKS AND BANKING CHAPTER 108267

2. counsel, accountants, or consultants employed by the commissioner or on the commissioner's behalf; Unsecured claims for wages, salaries, or commissions earned by an individual within ninety days before the date of the commissioner's possession in an amount not exceeding five thousand dollars for each individual;

3. Claims of depositors, except that notwithstanding sections 6-03-67 and 4104-27, if a depositor is indebted to an insolvent bank, the insolvent bank has a right to setoff against the depositor's account;

4. All other unsecured claims and claims of secured creditors to the extent the amount of their claims exceeds the present fair market value of their collateral;

5. Claims for debts that are subordinated under the provisions of a subordination agreement or other instrument; and

6. Equity capital of shareholders.

\section{Further particulars and coinciding factors}

There are no notable news items in the media about banks in North Dakota.

\section{$\underline{\text { Rhode Island ( } 8^{\text {th }} \text { February 1991) }}$}

\section{Party control}

Governor: D $\quad$ Party control upper and lower house: D 
Priority of claims - Federally insured financial institutions or credit unions. - In a receivership, or a conservatorship under chapter 11 of this title, of a financial institution or credit union whose deposits are insured by the federal deposit insurance corporation, the national credit union administration or any other agency or instrumentality of the United States, the allowed expenses and claims against the financial institution or credit union shall have priority in receiving distributions, out of the assets of the financial institution or credit union in the following order:

(1) The payment of costs and expenses of the administration of the receivership estate.

(2) The payment of claims for "deposits", as that term is defined in 12 U.S.C. § 1813(I), including, but not limited to, the claims of depositors in a mutual savings bank for return of their deposits.

(3) Unsecured claims of any local, state, or federal taxing authority entitled by law to priority in distribution from the receivership or conservatorship estate, to the extent of such priority.

(4) Claims of salaried employees of the financial institution or credit union for wages or salaries earned but unpaid as of the commencement of the receivership or conservatorship.

(5) Claims for all other general liabilities not specified herein.

(6) Claims otherwise proper that were not filed within the prescribed time.

(7) Claims for obligations expressly subordinated to deposits and general liability claims.

Any funds remaining shall be paid to the stockholders of the financial institution or credit union, or, in the case of a mutual financial institution in which there are no stockholders, to the depositors in proportion to the respective amounts of their stock or deposits.

Interest shall be given the same priority as the claim on which it is based, but no interest shall be paid on any claim until the principal of all claims within the same class has been paid or adequately provided for in full.

\section{Further particulars and coinciding factors}

Rhode Island was affected by the New England banking crisis. One of the main lenders in Rhode Island, First Financial Corp. of Providence, reports a substantial drop in earnings. Other news items report on poor performance of banks in Rhode Island, making them a vulnerable target for acquisitions.

\section{$\underline{\text { Texas }\left(26^{\text {th }} \text { August 1985) }\right.}$}

\section{Party control}

Governor: D Party control upper and lower house: D

\section{Legal provision}

Art. 4a. PRIORITY OF CLAIMS-PAYMENT. On liquidation of a state or private bank claims for payment have the following priority:

(1) obligations incurred by the Commissioner, fees and assessments due to the Department, and expenses of liquidation, all of which may be covered by a proper reserve of funds;

(2) claims of depositors having an approved claim against the general liquidating account of the bank; 
(3) claims of general creditors having an approved claim against the general liquidating account of the bank;

(4) claims otherwise proper that were not filed within the time prescribed by this Code;

(5) approved claims of subordinated creditors; and

(6) claims of stockholders of the bank.

\section{Further particulars and coinciding factors}

Texas experienced a series of bank failures. The state repealed its depositor preference provisions shortly prior to the introduction of national depositor preference in 1993 as a result of the FDIC's resolution of the First City banks that had been closed in October 1992.

The media reports that several banks experience problems with loans provided to the energy industry. 


\section{Appendix B: Regressions accounting for a charter time trend}

Table B.1 Accounting for a charter time trend

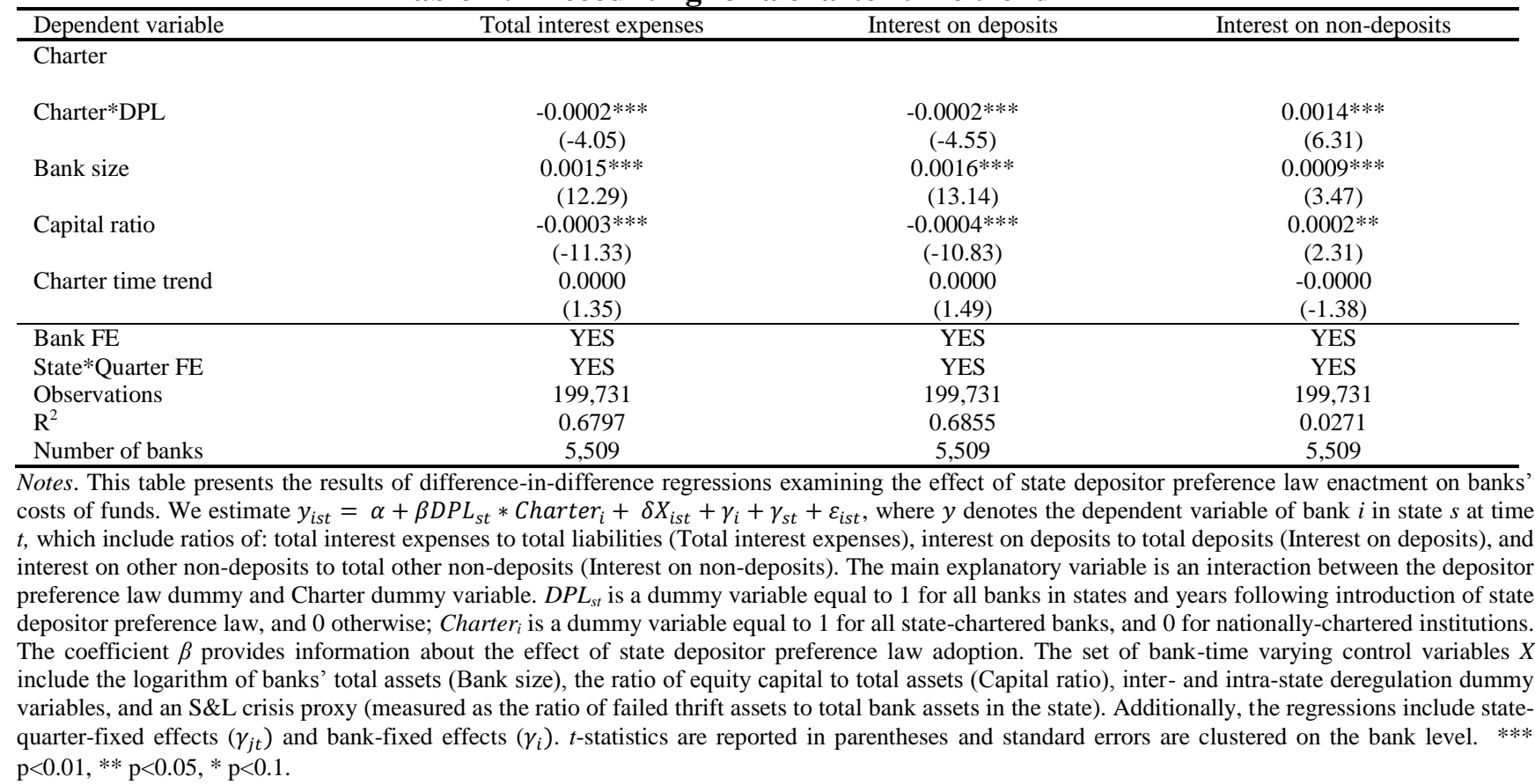

